Diartech S.s.

Roma, Italy

giovanamarresse@live.it

Original research article

PATRIZIA TUCCI

University of Rome La Sapienza,

Department of Earth Science,

Roma, Italy

ANGELINA RAIČKOVIĆ SAVIĆ

Institute of Archaeology, Belgrade, Serbia

\title{
ROMAN POTTERY FROM VIMINACIUM (SERBIA 2ND - 3RD CENTURIES AD): COMPOSITIONAL CHARACTERISTICS, PRODUCTION AND TECHNOLOGICAL ASPECTS
}

\begin{abstract}
This study presents the results of mineralogical, petrographic and chemical analyses of 58 specimens of pottery and eight kiln wastes from the archaeological site of Viminacium and allows the creation of a reference chemical and mineral-petrographic group.

Four representative samples of argillaceous sediment were characterised by mineral-petrographic analysis before and after firing tests at 600 and $900^{\circ} \mathrm{C}$. Comparisons of the characteristics of the pottery, kiln wastes and local clay established the source of the raw materials and production methods. Petrographic analysis enabled the division of the pottery into the following: i) four fabrics characterised by inclusions perfectly consistent both with the lithotype outcroppings in the immediate vicinity of Viminacium and clay and kiln wastes, therefore deemed to be of local origin; ii) seven petrographic "singles", three of which are of uncertain production.

Firing tests conducted at $900{ }^{\circ} \mathrm{C}$ on the clay samples showed (by PXRD) the formation of hematite, gehlenite and pyroxene phases (in samples with calcite and dolomite precursors), all of which were also present in the pottery deemed to be of local origin. XRF confirmed the divisions made on a mineral-petrographic basis. The identified textural properties indicate firing temperatures in the range of $700-1050{ }^{\circ} \mathrm{C}$.
\end{abstract}

\section{KEYWORDS: ARCHAEOMETRY, POTTERY, ROMAN AGE, VIMINACIUM, CLAY SAMPLES}

\section{INTRODUCTION ${ }^{1}$}

The archaeometric research described here was performed within the framework of collabo-

1 The article results from the project: IRS - Viminacium, Roman city and military legion camp - research of the material and non material culture of inhabitants by using the modern technologies of remote detection, geophysics, GIS, digitalisation and $3 D$ visualisation (no 47018), funded by the Ministry of Education, Science and Technological Development of the Republic of Serbia. ration between the Sapienza University of Rome and the Belgrade Institute of Archaeology.

The samples analysed in this work were collected from the archaeological site of Viminacium (VIMINACIVM), $100 \mathrm{~km}$ South East of Belgrade, Serbia (Fig. 1).

Viminacium was founded in the first decade of the $1^{\text {st }}$ century AD on the banks of the river Mlava, a tributary of The Danube, during the second part of the reign of Augustus or in the first part of that 


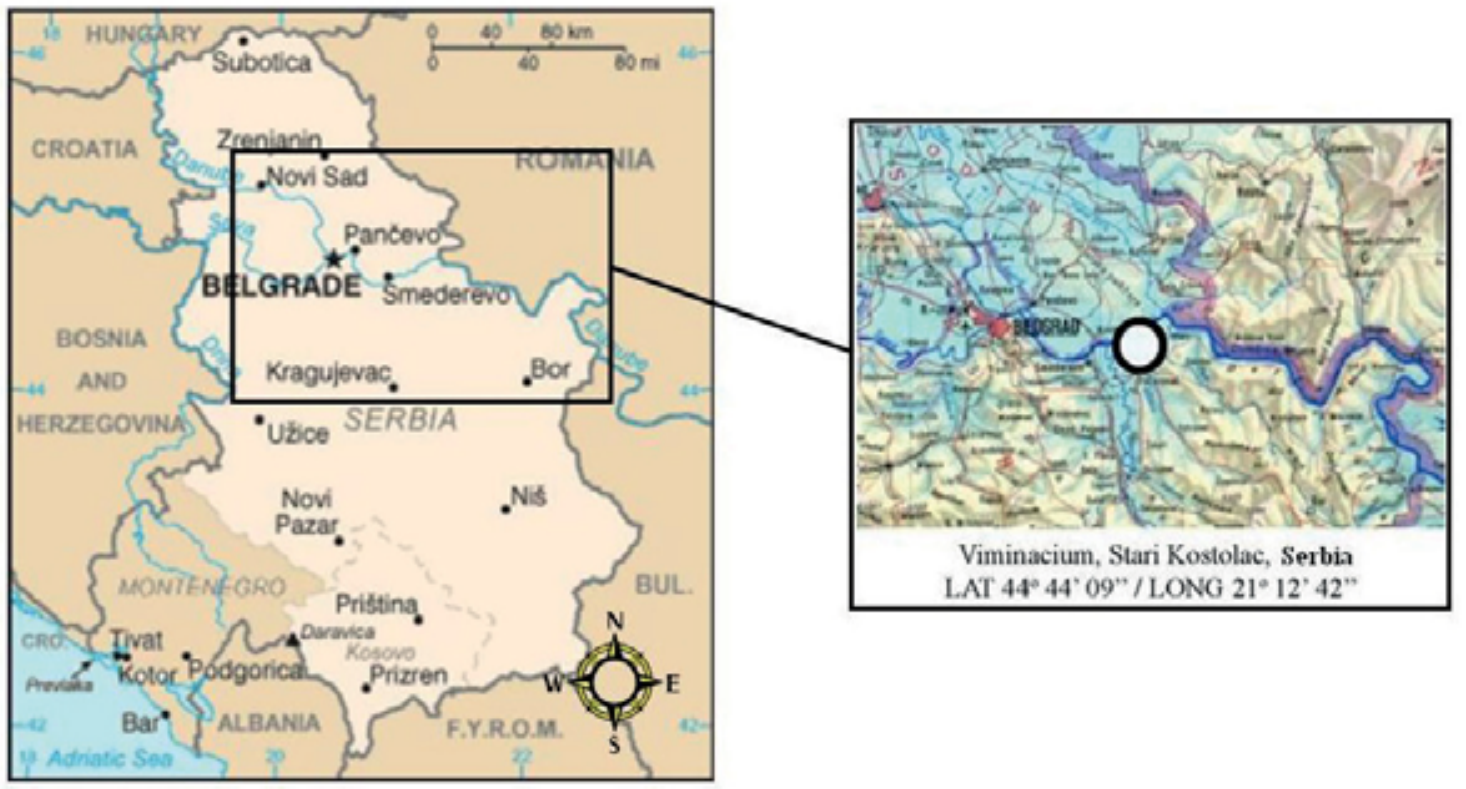

Fig. 1 Geographical map showing Serbia and the location of Viminacium with respect to Belgrade.

of Tiberius. Viminacium was a major city (provincial capital) and military camp of the Roman province of Moesia Superior (today's Serbia) during the period from the $1^{\text {st }}$ to the $4^{\text {th }}$ century AD. Its exceptional strategic importance was a result of its role in the defence of the northern border of the Roman Empire and, in turn, communications and commercial transactions. Also the hinterland of the Mlava valley, which was rich in metal ores and grains, was very attractive to the Romans. In Roman times, the northern side of the town relied directly on a branch of the Danube, while the western side touched the banks of the Mlava River. Viminacium did not spread to the left bank of the Mlava until a later period. Due to its location, land and waterways, in Viminacium, encounters between the cultures of the East and West were inevitable. Although roads primarily served a military and strategic function, they were a place throughout antiquity of lively traffic, and certainly contributed to Viminacium becoming very prosperous and an important trading and business centre. In the $3^{\text {rd }}$ century AD, it was established for a few decades as a city that minted coins, mostly of copper but also silver, for the armies of the Limes Moesicus. Viminacium was destroyed in
441 by Attila the Hun but was rebuilt by Justinian I during Maurice's Balkan campaigns. It suffered destruction by the Avars in 582 but was then home to the crushing defeat of the Avar forces on the northern Danube bank in 599, which destroyed the Avar reputation of invincibility.

Over the last three decades of the 20th century, site excavations were conducted in an increasingly accurate and systematic way (Korać 2006: 7). The excavations have brought to light a number of public structures (Fig. 2), such as an amphitheatre for 12,000 spectators, an aqueduct, baths, and what seems to have been a circus over the ruins of the legionary fortress and canabae, where many veterans of the legions of the area were settled. The surface area for archaeological investigation is exceptional (over 450 hectares for the greater metropolitan area and 220 hectares in the territory of the city). The remains of Viminacium extend over entire cultivated fields and fragments of, and sometimes whole, ancient artefacts lie scattered on the surface.

More than 13,500 graves have also been investigated, from which over 32,000 objects have been recovered. For this reason the city was named the "Pompeii of the Balkans". 


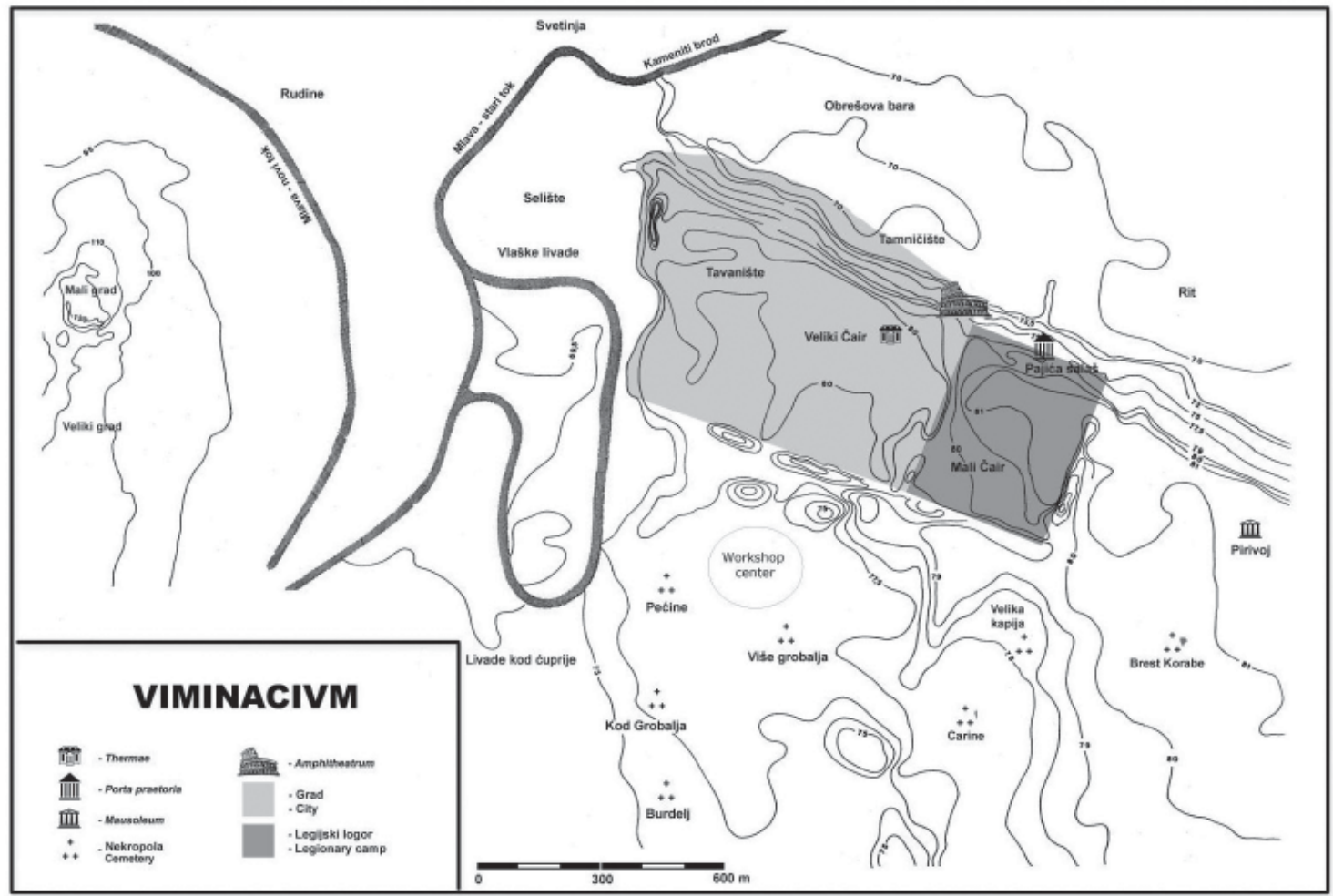

Fig. 2 Map of archaeological site of Viminacium.

During research on the whole area of Viminacium, more than 40 ceramic kilns were discovered, while 13 of them were excavated in the territory of the south necropolises of "Pećine" and "Više Grobalja". A group of kiln wastes (derived from the production of pottery and bricks) were also discovered nearby, and it has, therefore, been assumed that the area served as a workshop centre (Raičković and Redžić 2006a: 82; Raičković and Vuković 2009: 11; Raičković 2007: 55, Fig. 3).

Viminacium produced highly developed crafts (Raičković and Milovanović 2008: 27), with the production of ceramics especially abundant.

Production at this centre was active from the end of the $2^{\text {nd }}$ century AD until the end of the $3^{\text {rd }}$ century AD.

The workshop centre produced ceramic material necessary for the grave inventories of the necropolis, but further research (Raičković 2007: 50 .) has shown that only $20 \%$ of the forms produced there were used as a grave inventory. The other products of the workshop were vessels that were used in other markets. There is evidence to support such a theory from all localities of Moesia Superior and from other surrounding provinces, such as Pannonia and Dacia (loc. cit.)

After macroscopically analysing and typologically classifying more than 16,000 fragments of ceramic vessels from this area, it was suggested that some forms of the vessels were produced in the workshop centre, while some others were imported to Viminacium.

The aims of this work were as follows:

Verify (through the mineralogical-petrographic characterisation and chemical compositions of 58 fragments) the archaeological hypothesis of the local production (Raičković and Redžić 2006a: 87) of most of the samples studied, which represent different functional classes produced at Viminacium (Table 1), a marginal provincial area;

Determine whether the recognised forms, extraneous to local tradition (Raičković 2007: 39), were made with local raw materials (circulation of styles) or were imported (transport of finished goods);

Suggest the source or sources of supply (pot- 

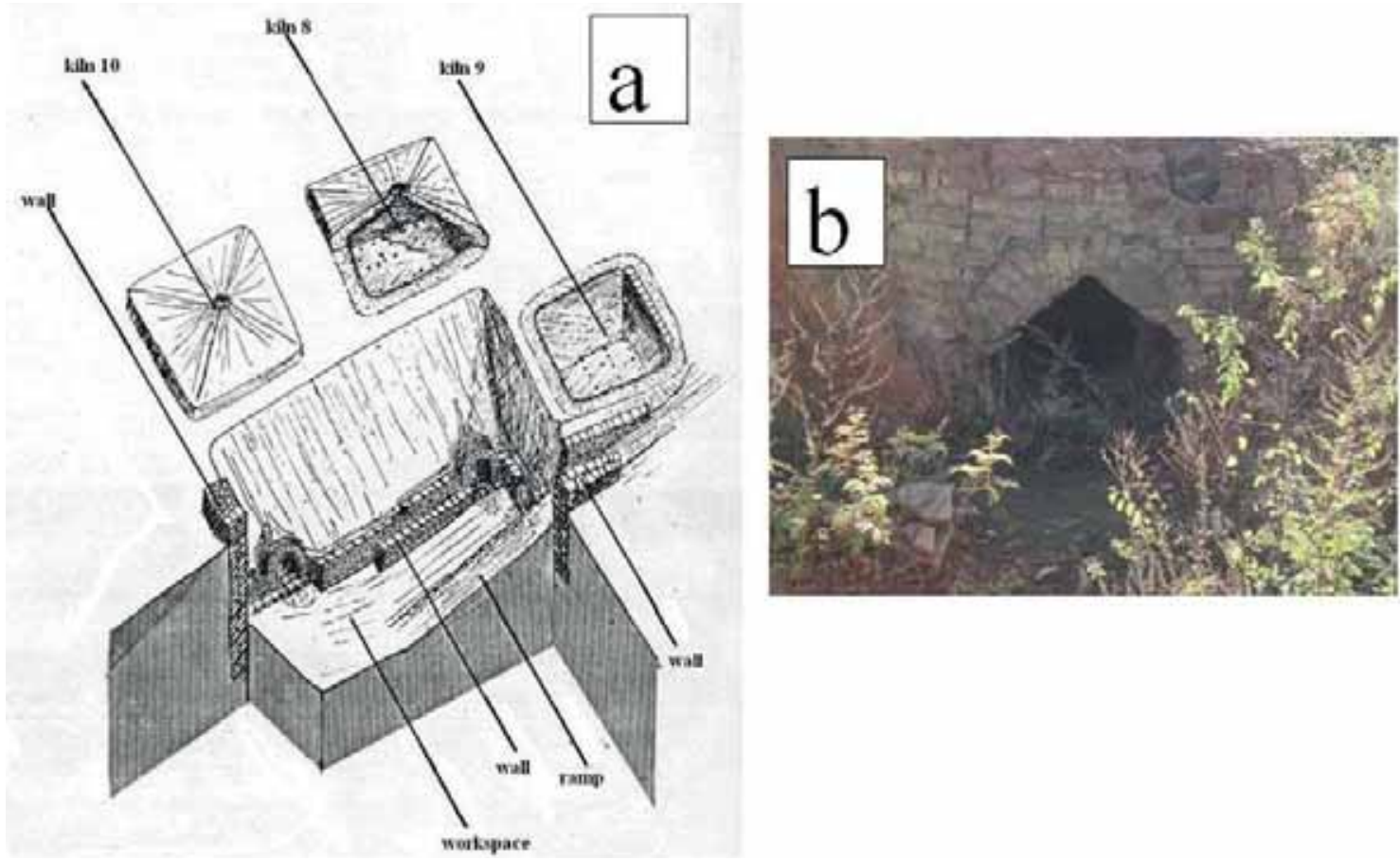

Fig. 3 a) Drawing of Pećine workshop center. b) Photograph of the kiln in Pećine workshop center, near which were taken eight kiln wastes studied.

ters movements and organisation of production) from the study of available lithological data found in literature (Dimitrijević 1997: Fig. 4a-b) and the mineralogical-petrographic study of four clay samples that are representative of clay variability in the immediate vicinity of the site;

Create a chemical and mineralogical-petrographic classification of ceramics produced in Viminacium that will be useful for future comparisons with other pottery from the same period and other Roman provinces.

It is important to emphasise that only a partial chemical analysis of pottery (Walton 2010: 733759) has been performed in Serbia so far. This is the first time that a chemical analysis has been conducted on Viminacium's pottery and, therefore, it is important for confirming the large production of pottery there and establishing the area across which it was distributed among other Roman provinces.

Several technological and production aspects, such as firing temperatures, production methods, finishing and decoration, were also assessed to determine the skill of the craftsmen at Viminacium.

\section{MATERIALS: CERAMICS, KILN WASTES, GEOLOGICAL SKETCH AND RAW CLAY MATERIALS}

In the immediate vicinity of "Pirivoj", a large area (Raičković and Milovanović 2009: 7-29) of red burnt soil was found in the same area where significant amounts of mobile material were also found (Fig. 2). Mobile material that is chronologically sensitive (coins, fibulae and glass vessels) makes chronological dating easier. The space itself was first considered to be a big pyre, but by the end of this study it was considered to be a rubbish heap used for the necropolis's waste (Raičković and Milovanović 2009: 27).

The 58 pottery fragments studied here (dated from the second half of the 2nd century to the end of the 3rd century AD) were collected near "Pirivoj", around the Mausoleum (Fig. 2), during excavation number 29 (Fig. 5), which covered an area of $20 \times 20 \mathrm{~m}$ to a depth of $3 \mathrm{~m}$.

In sampling, all types of vessels produced at Viminacium were represented, including those used to prepare food, such as pots, jugs and bea- 


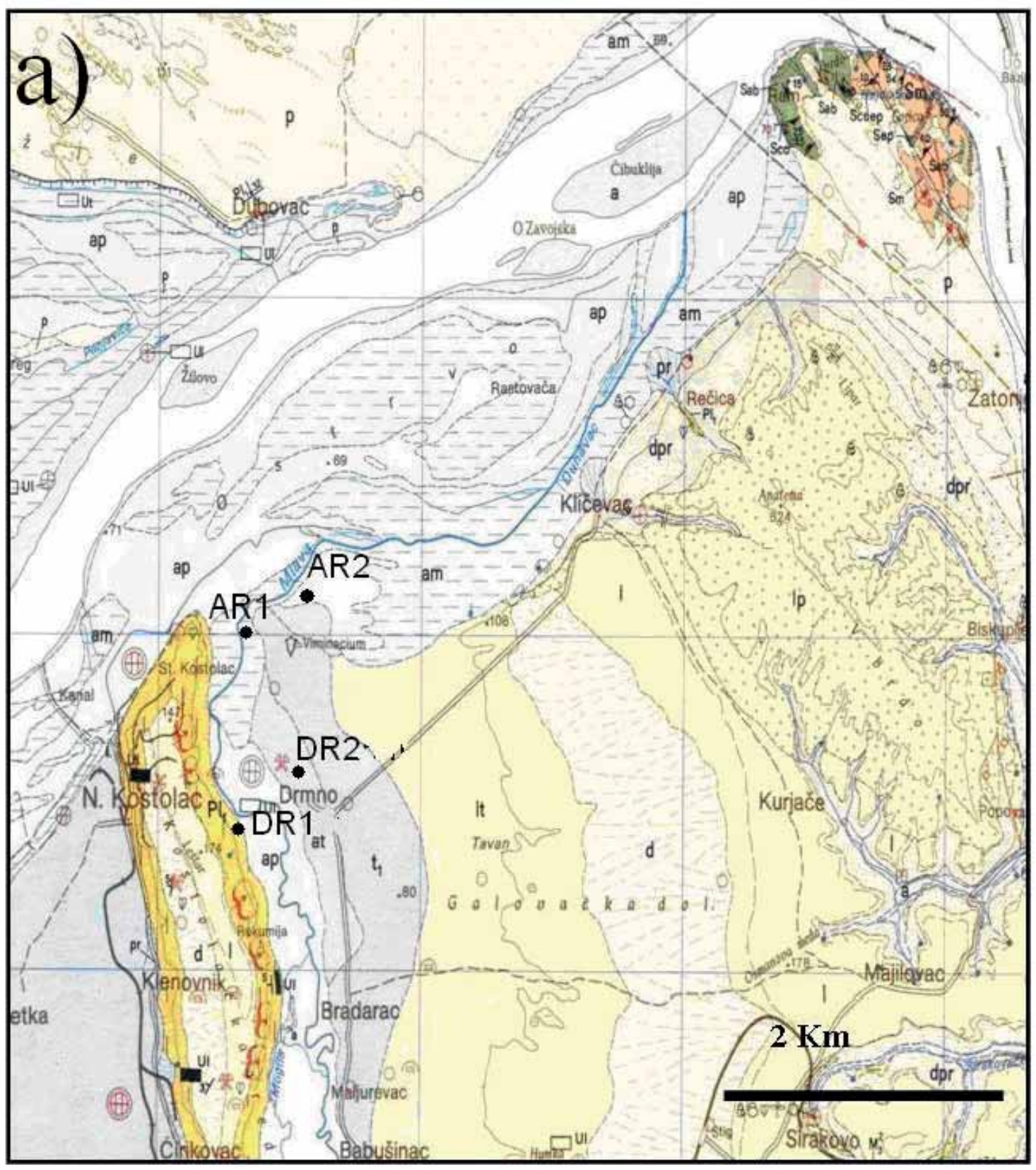

Fig. 4 a) Geological map of Kostolac and Drmno and legend. Sampling point of four clay samples.

kers, and those used for its storage and transport, pithoi and amphorae (Fig. 6). More than 99\% of detected pottery was moulded on a lathe.

The analysed fragments were chosen according to several criteria. First, the samples included each vessel type found at Viminacium (bowls, pots, plates); then from them, fragments made of macroscopically different types of clay were chosen.

Among the vessels used for preparing and cooking food, the so-called kitchenware (Table
1), were mainly forms of pots made of grey sandy clay (sample numbers $=$ s. n. 9, 13, 21, 25, 29 and 56 Fig. $6_{8}$ ) or that had red mixtures (s. n. 8, 10, 27, 43, 49, 53 and 57). Some of them (s. n. 22, 50 and 58) contain white fragments, which may be pieces of bioclasts.

As for tableware (Tab. 1), the ceramics were mainly made of partially refined clay that had grey or red mixtures (Fig. $6_{1-2}$ ), and the outer surfaces were often coated with different shades of 

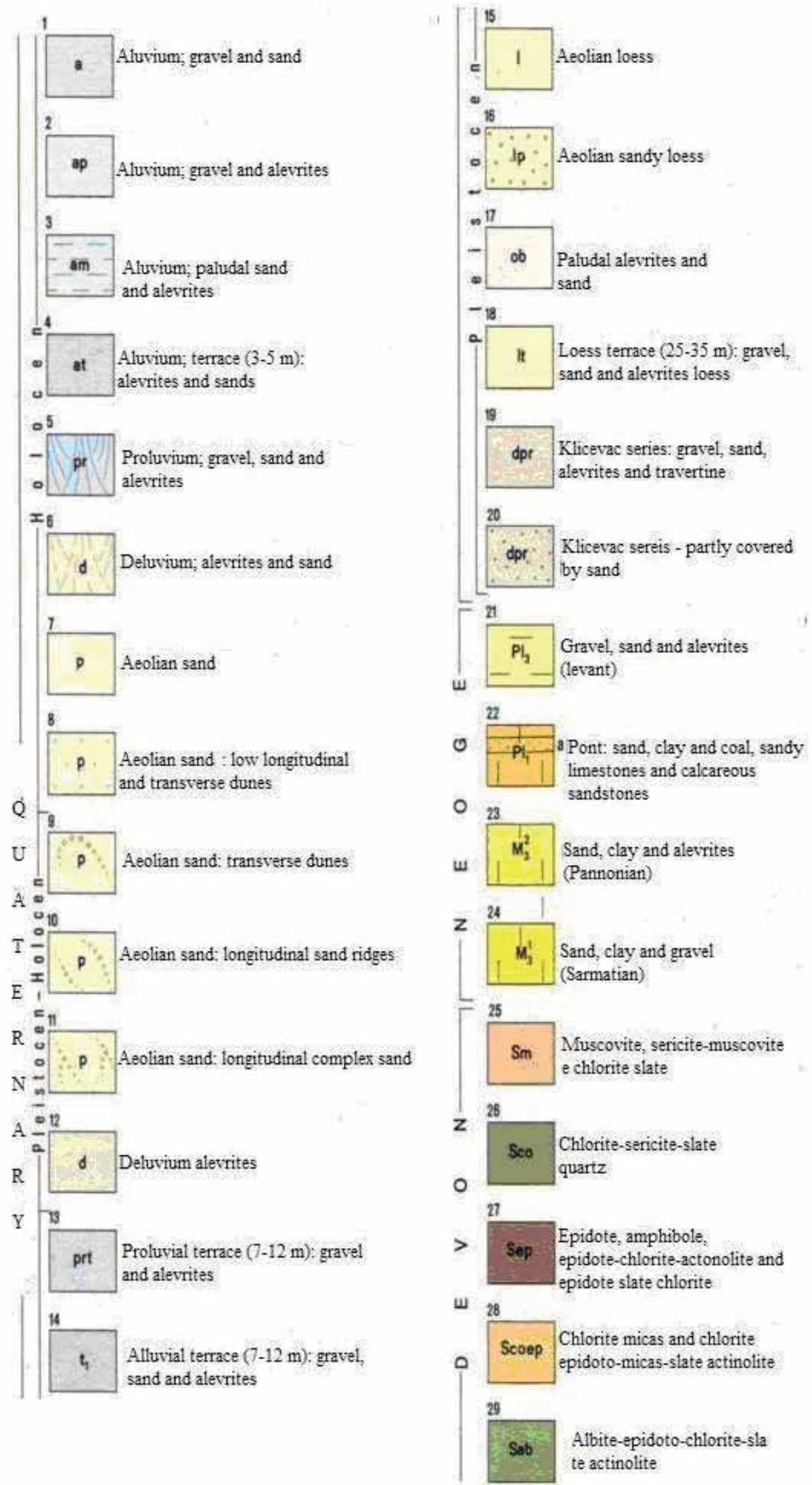

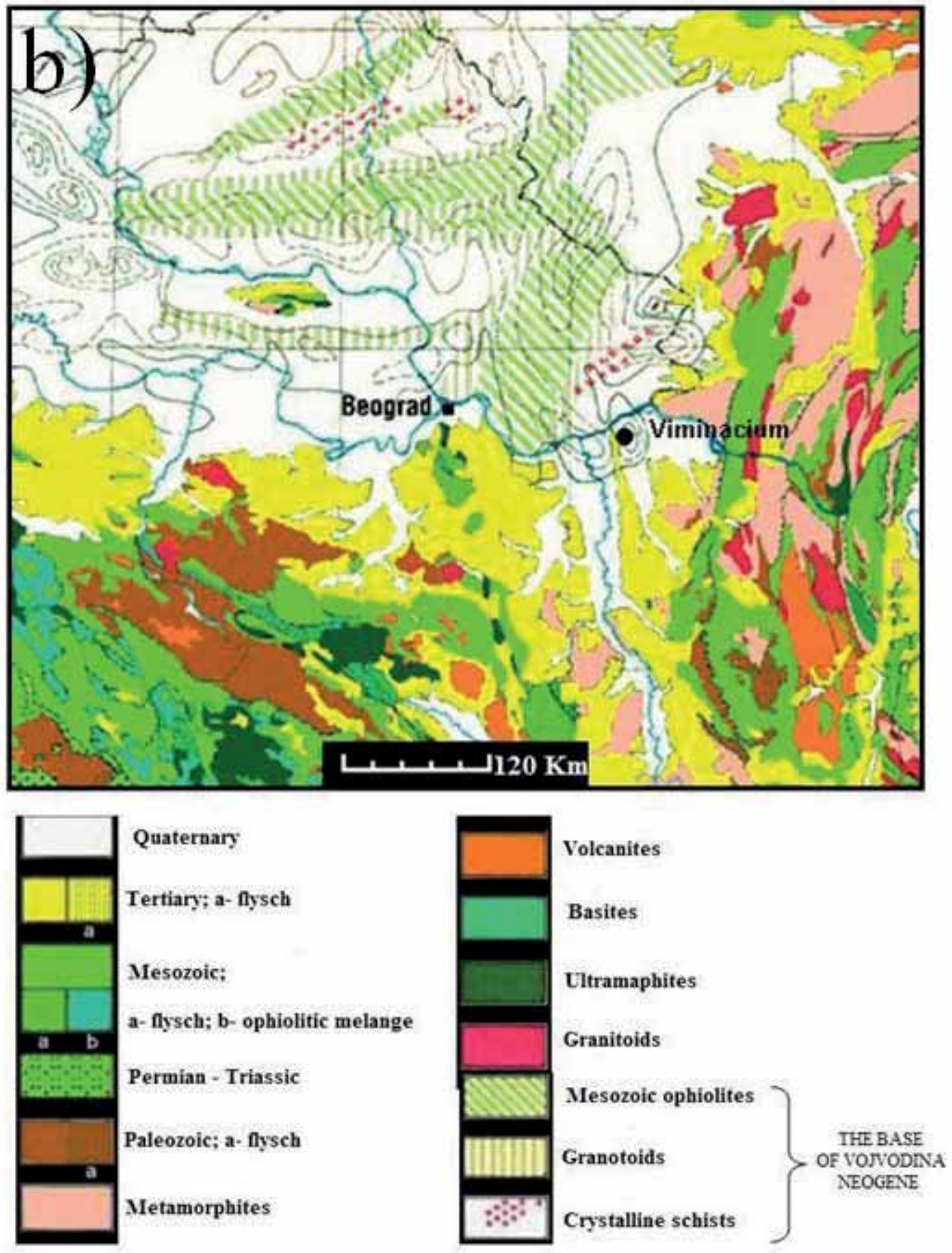

Fig. 4b) Geological map of Serbia and legend.

red (s. n. 11, 12, 24, 31, 36, 37, 51 and 59). In this group, there were a number of forms recognised as imports (Raičković 2007: 43) made of finely refined clay in white (s. n. 23; Fig. 7a), red (s. n. 38; Fig. 7b) and grey (s. n. 41; Fig. 7c) as a result of firing, where the decorations on the outer surfaces were different (stamps and incisions) or the surface was painted with a stable colour or glazed in light green shades (s. n. 20; Fig. 7d).

Among vessels used for the transport and storage of food, the amphorae and pithoi samples made of different macroscopic fabrics were chosen in the range of sandy clay (Fig. $6_{3-7}$ ) with different ingredients (4, 17, 46 and 47). According 


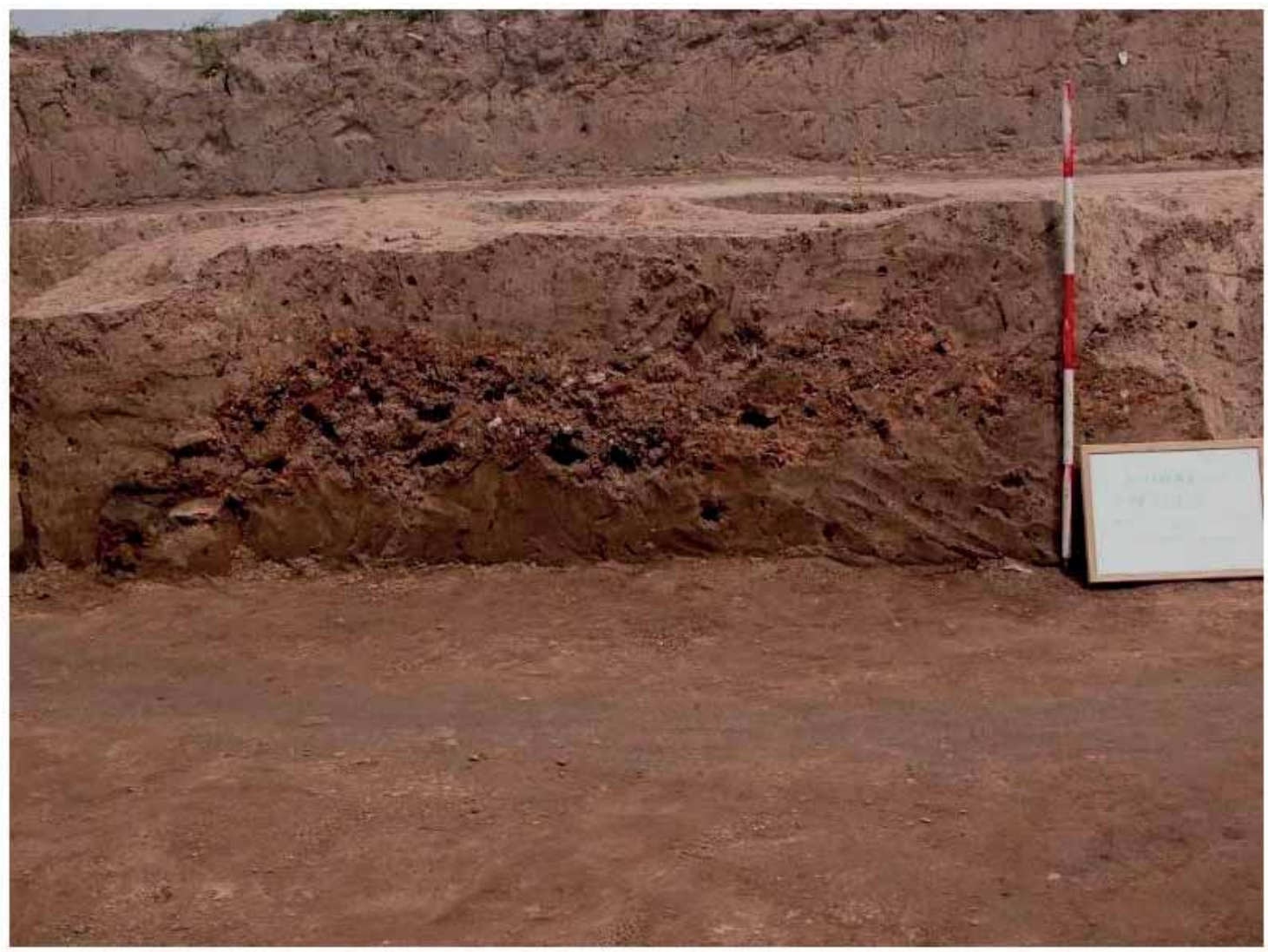

Fig. 5 Excavation number 29, Necropolis of Pirivoj.

to archaeologists (ibid. 42), the forms of sample numbers 4, 17 and 46 are not of local origin.

The kiln wastes were only broken pieces of mostly unfired ceramics recovered from a kiln dump located in the workshop centre of "Pećine", which was outside the city, near the necropolis. It was impossible to establish the function of the kiln wastes.

Fig. $4 \mathrm{a}$ shows that in a radius of $10 \mathrm{~km}$ from the archaeological site there is only the presence of sedimentary rocks, mostly alluvial terraces of the river Mlava (Quaternary). In fact Viminacium is located within an alluvial terrace $(7-12 \mathrm{~m})$ consisting of gravel, sand and silt. At the edge of this area and to the east lies a terrace of very fine eolic sediment (25-35 m thick) and to the west of the alluvium, a terrace 3-5 m thick composed of silt and sand. To the north of the alluvium, however, are old facies of sandy swamp and silt, alternating with younger facies of sandy alluvials and siltstones. In the area of Stari and Novi Kostolac (about $3 \mathrm{~km}$ west and south-west of Viminacium) there is a strip of land consisting of sand, clay and coal, sandy limestone and carbonate sands. Within this area there is different lithology characterised by very thin sandy eolic sediment.

About 10 kilometres north-east of the archaeological site, there is an area of approximately 5 $\mathrm{km}^{2}$ comprising metamorphic rocks, particularly schists with mineralogical associations such as:

1) Muscovite, Muscovite-sericite-chlorite;

2) quartz, chlorite-sericite;

3) epidote-amphibolite, epidote-Chlorite-Actinolite;

4) Chlorite-Mica and Chlorite-epidote-mica-Actinolite;

5) Albite-Chlorite-epidote-Actinolite.

Fig. 4b (Dimitriević 1997) instead, shows that Viminacium's area is bordered to the N-NW by an outcrop of crystalline schists and Mesozoic Ophi- 

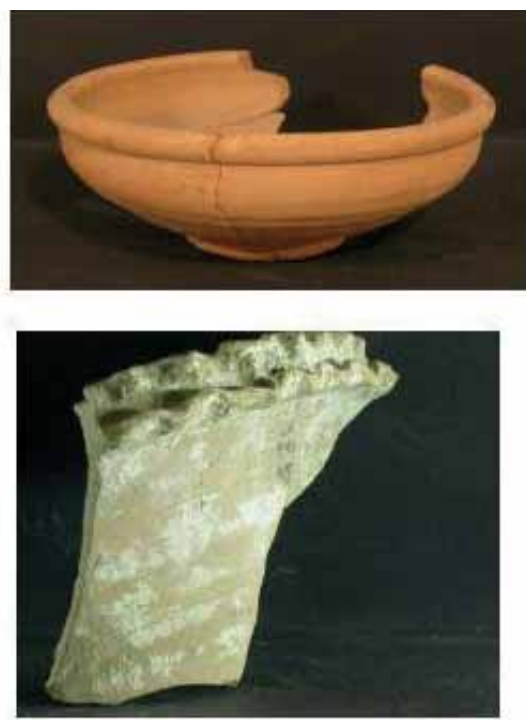

1
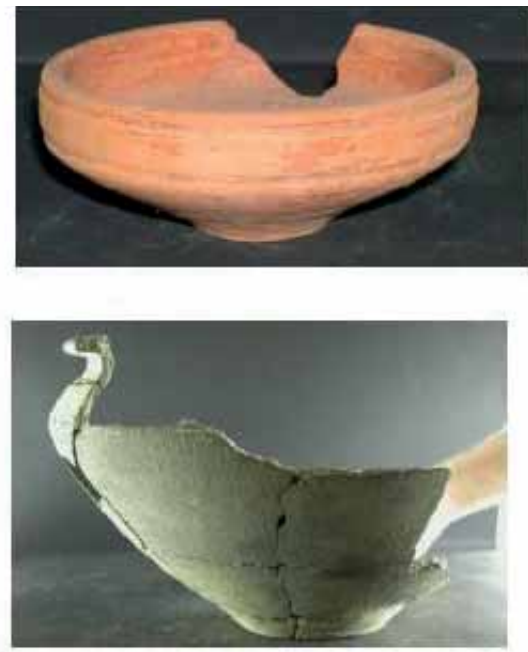

3

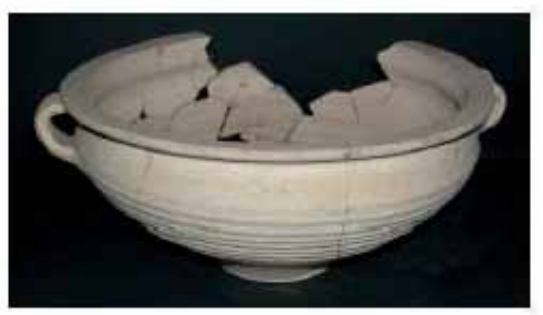

5
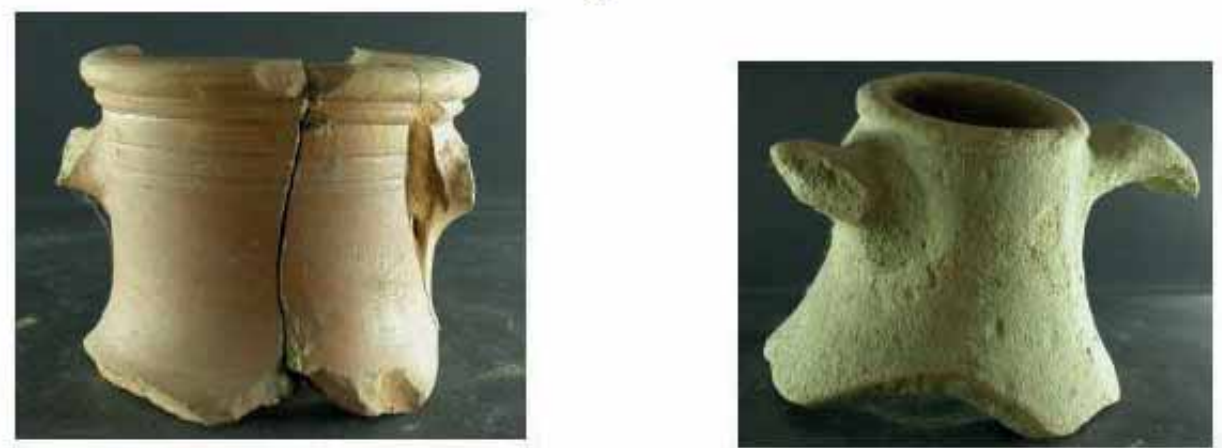

2

4

6

7

Fig. 6 Kinds of vessels produced at Viminacium and sampled. 1) (Tableware) medium fine texture clay, red fabric; 2) (Tableware) medium fine texture clay red fabric, outer surface colored in different shades of red; 3) (Amphora) medium fine texture clay red fabric with outer surface yellowish white engobe; 4) (Tableware) sandy clay, grey fabric;

5) and 6) (Tableware) sandy clay, white fabric; 7) (Amphora) medium fine texture clay red fabric, outer surface colored red; 8) (Kitchenware) sandy clay, dark fabric.

olites; to the NE by a Tertiary flysch adjacent to granitoid and metamorphic rocks and a Paleozoic flysch; to the E by metamorphic rocks and to the $\mathrm{S}$ by Mesozoic alluvial deposits in an area with metamorphic rocks and a small number of granitoid rocks.

Four clay samples were selected from different points around Viminacium for analysis (Fig. 4a): two were near the Mlava River (AR1 and AR2; Fig. 2); two were taken from Drmno, a town $3 \mathrm{~km}$ from the old city (DR1 and DR2). The samples were representative of four outcrops of clay in the vicinity of the site (loc.cit.), but they were not certain to be likely points for the collection of mate- 


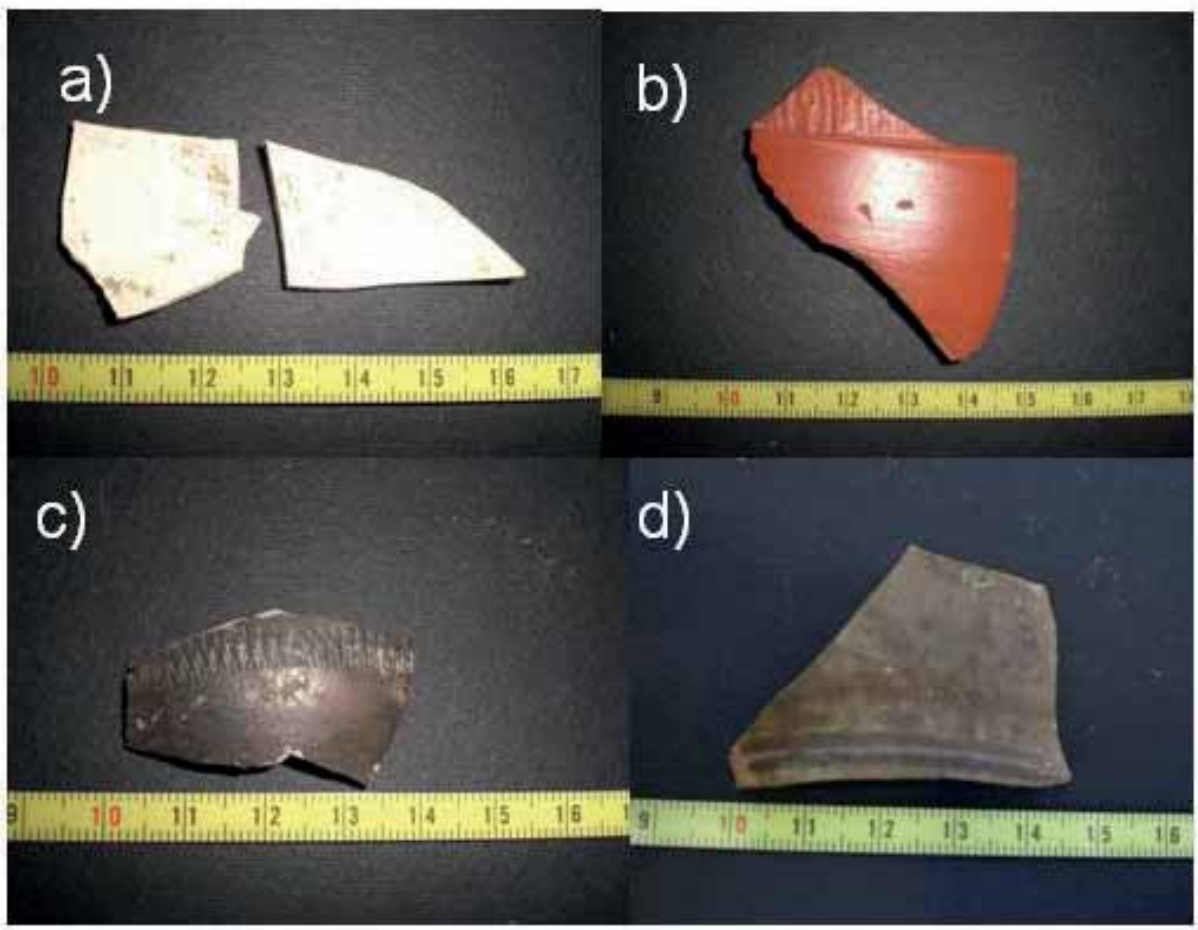

Fig. 7 Some forms recognized as imports: a) Sample 23; b) Sample 38; c) Sample 41; d) Sample 20.
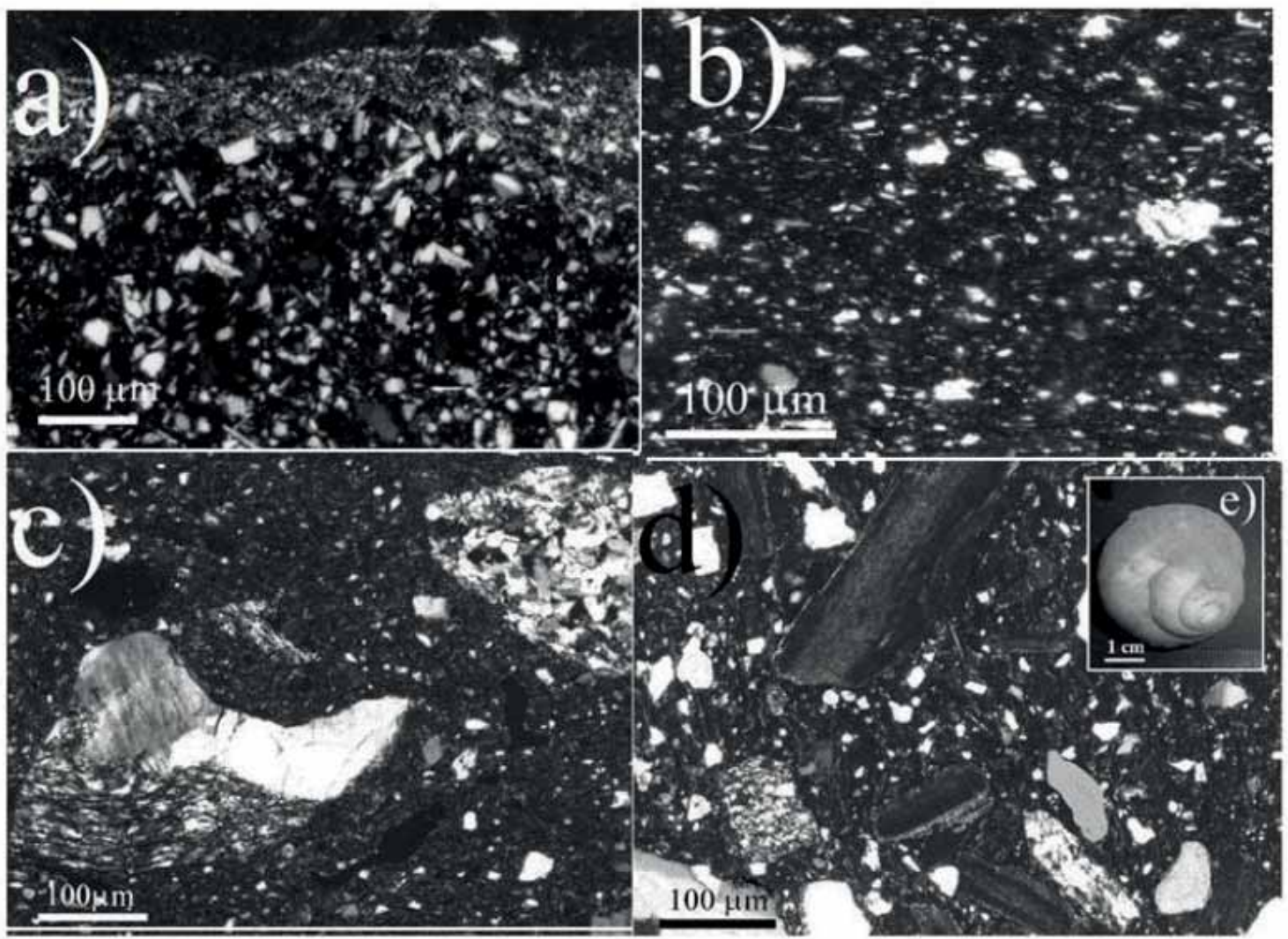

Fig. 8 Thin-section microphotographs by optical microscope of two fabric types and subgroup of coarse-grained group (crossed Nicol prisms): a) Fabric 2; b) Fabric 1 (quartzose component with sharp edges); c) Fabric 3A (hiatal with metamorphic rocks); d) Fabric 3B (fragments of gastropods); 6) One of many shells found on the site, maybe part of the ancient diet. 


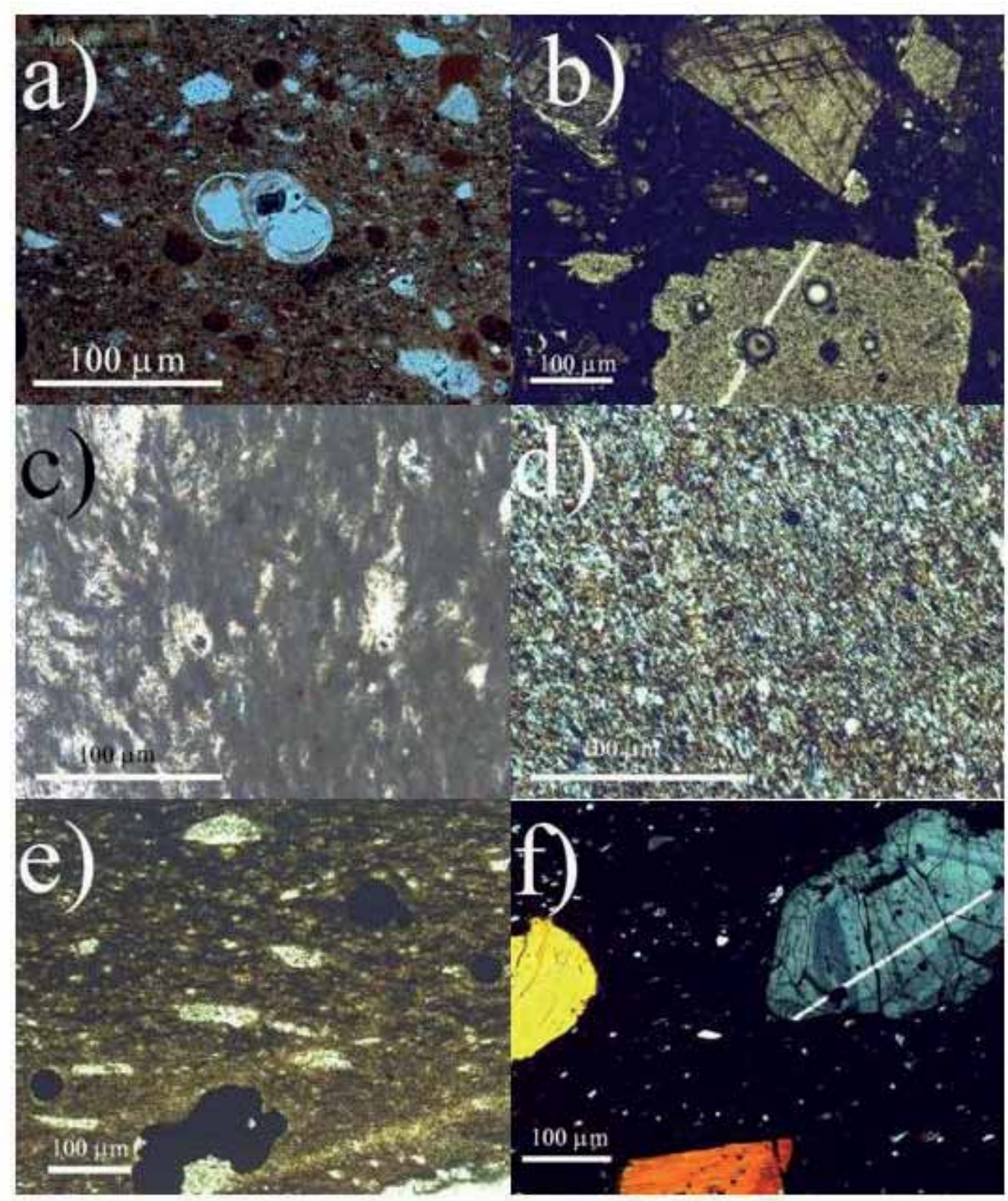

Fig. 9 Thin section microphotographs of petrographic singles: a) Sample 4; b) Sample 9; c) sample 23; d) Sample 38; e) Sample 41; f) Sample 46.

rial for the ancient potters and come from a mine whose depth is unknown. For these reasons, it was not considered appropriate to perform chemical analysis on these samples of clay, so only a mineralogical-petrographic analysis was performed. Samples AR1, AR2 and DR2 come from quaternary alluvial deposits (Holocene); sample DR1 is a Neogene calcareous clay.

\section{ANALYTICAL METHODS}

Each sample was powdered in an agate mortar and then subjected to X-ray diffraction (PXRD) and X-ray fluorescence (XRF) analyses.

PXRD was performed using Philips PW 1830 equipment, with filtered $\mathrm{CuK} \alpha$ radiation $(40 \mathrm{mV}$, $20 \mathrm{~mA}$ ), which measures $3-70^{\circ} 2 \theta$ at a velocity of $1 \%$ min and a time step of $2 \mathrm{~s}$, with a $1^{\circ}$ divergent 


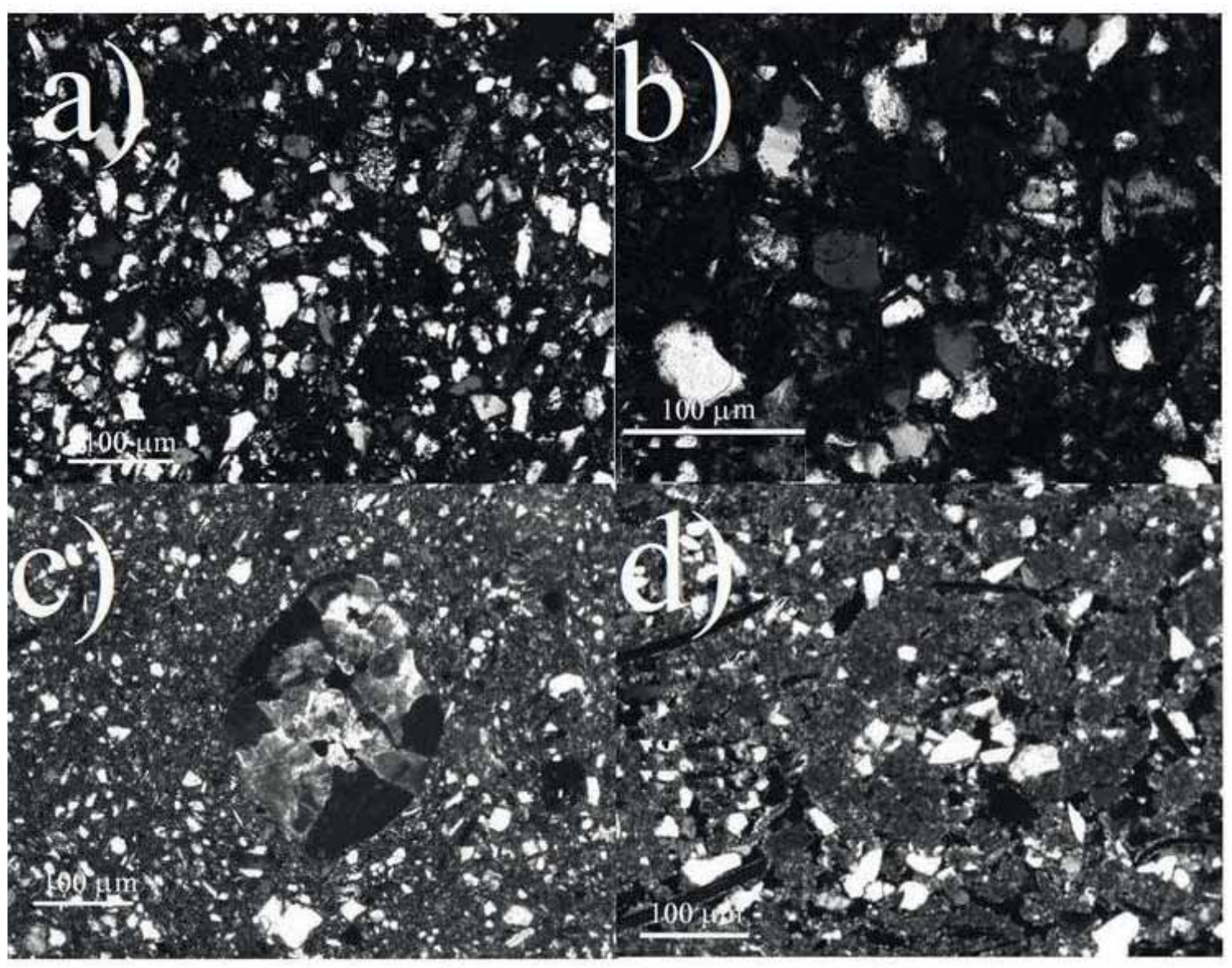

Fig. 10 Thin section microphotographs by optical microscope of clay samples: a) AR1; b) DR25m; c) AR2, in evidence calcareous pellets; d) DR15m.

slit, $0.1 \mathrm{~mm}$ detector slit and $2^{\circ}$ anti-scatter slit.

Thin-section analyses of the fabric of the archaeological specimens were performed using a Zeiss polarising microscope, which distinguished between inclusions (skeleton), matrix and voids (Maggetti 1982:121-133; Whitbread 1995).

Major and trace element determination was performed by means of XRF on $2 \mathrm{~g}$ of powder, previously calcined, using glassy pearls (prepared with an automatic Philips PerlX-2) with a ratio of ceramic powder and melt of 1:4, and with a RIGAKU ZSX PRIMUS spectrometer (Rigaku International Corp., Osaka, Japan), according to Franzini et al. 1975 and Leoni \& Saitta 1976.

Calcination by L.O.I. was determined by heating the powder at $1000{ }^{\circ} \mathrm{C}$ for $24 \mathrm{hrs}$. Analytical precision was generally estimated at $<3 \%$ for major elements and better than $10 \%$ for trace elements.

The clay materials were subjected to petrographic analysis and X-ray diffraction (XRD) to define their compatibility, or otherwise, with ceramic materials. To obtain suitable material to study in thin sections and a concrete base for the comparison of pottery considered local, clays were mixed with water and moulded into the form of small bricks measuring $2 \times 3 \times 1 \mathrm{~cm}$. These were first dried at room temperature for 2 days in order to eliminate the mixing water and then cooked, for firing tests, in a muffle kiln, in an oxidising atmosphere (the supposed mode of firing for most samples studied, inferred by fabric analysis) at 600 and $900{ }^{\circ} \mathrm{C}$ for $6 \mathrm{hrs}$. 


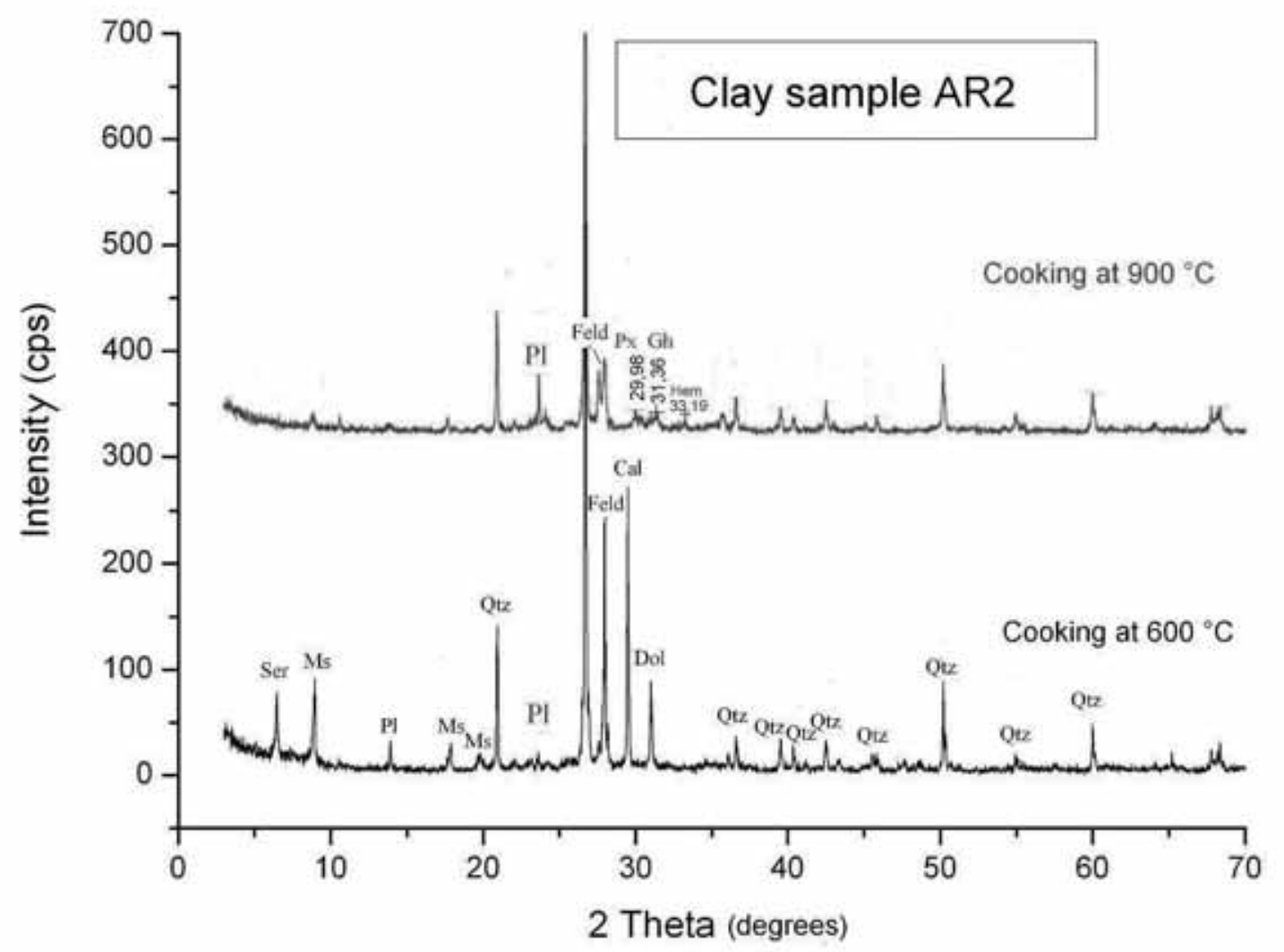

Fig. 11 Diffractograms showing comparison and different mineralogical phases between clay sample AR2 cooked at 600 and $900^{\circ} \mathrm{C}$. Ser, sericite; Ms, muscovite; Pl, plagioclase; Qtz, quartz; Feld, feldspar, Px, pyroxene; Gh, gehlenite, Cal, calcite; Dol, dolomite; Hem, hematite (symbols as in Kretz, 1983).

\section{RESULTS}

\section{Optical microscopy}

The samples were petrographically observed for functional class using optical microscopy. An accurate comparative examination of the results revealed not only recurrent similarities, but also differences among samples of the same type, which enabled the division of most of the fragments into different fabrics (Fabric 1, 2, 3A and 3B) based on the composition of their aplastic component.

Seven samples $(4,9,17,23,38,41$ and 46) were so unique that it proved impossible to attribute them to any fabric type, and they were therefore regarded as petrographic "singles".

Petrographic observations also allowed the classification of the eight kiln waste samples, as with the pottery, as Fabric 1 (sample II), Fabric
2 (samples I, III, IV, V and VIII) and Fabric 3A (samples VI and VII).

The proposed quantification of the inclusions present in the samples was a semi-quantitative estimation made using comparative tables (Cuomo di Caprio, 2007: 21-40).

\section{Tableware}

This group of 27 samples (Table 1) is characterised by 2 fabrics (Fabric 1 and 2) and 3 petrographic "singles" (samples 23, 38 and 41).

The two types of dough differ in the absence (Fabric 1; samples 20, 24, 26, 37, 42, 52, 55 and 60 ) or occurrence (Fabric 2; samples 1, 3, 7, 11, $12,15,28,31,32,34,36,39,40,49,51$ and 59) of scarce and very fine, rounded fragments of calcareous pellets and calcite (Fig. 8a) and the presence 
(Fabric 1) of frequent fine metamorphic-quartzose rock fragments, sometimes with sharp edges (Fig. $8 b)$.

For this type of pottery, the paste had a granulometry from fine to very fine, from homogeneous to serial, with packing that was low to medium ands sorting that was from good to moderate (Fig. 8a). The aplastic component (inclusions $\leq 20-30$ $\square \mathrm{m}$; Whitbread 1995) had rounded edges, with the exception of specimens $20,24,37,55$, and 59, where the quartzose component had sharp edges (Fig. 8b). The composition of the skeleton was predominantly monocrystalline quartz, plagioclase, variably abundant micas that were often oriented in the direction that the clay was worked and rare K-feldspars with rounded edges. Of the micas, muscovite was more abundant than biotite. Low to very scarce quantities of small iron oxides and hydroxides were present in almost all samples and clay pellets (Whitbread 1986: 79-88) could often be identified.

The entire specimen set was characterised by low porosity and compactness and in specimens $3,11,32,35,40$ and 59, calcite from recrystallisation was frequently observed. In samples 35 and 40 rare and very small crystals of sericite were noted. The matrix content ranged from a minimum of $60 \%$ to a maximum of $90 \%$ by volume, and the ceramic bodies showed chromatic zoning due to varying degrees of oxidation of the matrix. Most samples presented a matrix without birefringence. Additionally, less of a birefringent black core in comparison to a birefringent brown-orange border was not very common (samples 20, 36,52 and 55).

\section{Kitchenware}

This group of 15 specimens (Table 1) included 2 fabric types very similar to each other (which from here on will be called Fabric 3: A and B) and one petrographic "single" (s. n. 9). Fabric 3B can be considered a subgroup of Fabric 3A.
Fabric 3A (s. n. 8, 10, 13, 21, 25, 27, 29, 43, 53, 56 and 57) and 3B (s. n. 22, 50 and 58) contained coarse-grained samples and had a medium-high concentration of the lithic fraction; it was poorly sorted and had a generally hiatal granulometric distribution. The non-argillaceous fraction was distinguished mainly by two different granulometric classes (Fig. 8c).

The inclusions (the larger component, which were clearly tempered) were for the most part sharp-edged and only in rare cases were rounded. Mineralogical phases in decreasing order of abundance were: polycrystalline quartz with a typically undulose extinction, crystals of micas (mainly muscovite and sericite only in specimen 21) and plagioclases. Subordinates included K-feldspar and granules of monocrystalline quartz; this component belongs to the smallest granulometric class and is often characterised by rounded edges. Lithic inclusions were frequently metamorphic-quartzose and metamorphic-schistose rock fragments, which belong to the largest granulometric class and have a sharp edge. Chamotte (Cuomo di Caprio and Vaughan 1993: 21-40) was frequent in most samples. Porosity was more marked and compactness thereby lower than that of the first group.

Fabric 3B shows fragments of either freshwater or terrestrial gastropods (Fig. 8d) in addition to the bigger inclusions of hiatal granulometric distribution, which, based on the many shells found on the site (Fig. 8e), may have been part of the ancient diet (Raičković, 2007: 44). The fragments were oriented in the direction of the long sides of the sherds. Both macroscopic observation of the samples (blackened walls, coarse grains on fractures and high porosity) and microscopic inspection (a very dark-coloured matrix and the rather coarse granulometry of the fabric) suggested that all three samples were potentially used for firing. In sample 22 rare crystals of sericite were noted. 


\section{Amphorae and Pithoi}

This group of 16 samples was characterised by 2 fabrics and 3 petrographic "singles" (s. n. 4, 17 and 46).

Samples 2, 5, 14, 30, 33, 47, 48 and 54 were found to be Fabric 1 (similar to part of the tableware), and the remaining samples were Fabric 2 (similar to part of the tableware).

All samples in this group, except for the petrographic "singles", had a quartzose component with sharp edges (Fig. 8b).

\section{Petrographic "singles"}

According to their microscopic features, seven samples were deemed to be of different production and were therefore considered to be petrographic "singles" (Fig. 9).

Sample 4 (amphora): The sample was medium to highly packed and had a poorly sorted matrix, coarse granulometry, and a serial structure. Fossils were very abundant in these samples (whole shells and fragments of planktonic foraminifera and Pliocene Globigerinidae) but were not found in other samples. Various oxides together with fragments of quartzose metamorphic rock and mineral components represented by quartz, gypsum, plagioclase and micas also occurred.

Sample 9 (kitchenware): The sample was extremely coarse with a fractured fabric and very high porosity. Large, sharp-edged fragments of carbonate rock, calcite crystals, quartz, and rare plagioclase and micas were clearly visible.

Sample 17 (amphora): The sample was rather coarse with a high-porosity granulometry that was oriented in the direction that the sherd was worked. Inclusions were represented by somewhat round-edged quartz, very sharp calcite, opaque iron oxides and clay clumps.

Sample 23 (tableware): The sample showed almost no packing at all, had a light-coloured purified matrix with only a few minuscule quartzose inclusions which were highly compact. The considerable differences between specimens could be confirmed macroscopically due to the extreme thinness and white colour of the ceramic body.

Sample 38 (tableware): The sample showed very scarce packing and was composed of purified clay, rare, tiny fragments of quartz and sporadic small clay clumps. It was concluded that this sample was surely a different production because quite different techniques seem to have been used. For example, although the coarsest components were completely eliminated from the paste, oxides and clay clumps were scarce, whereas such components were frequent in fine-grained vessels, which were also almost completely free of inclusions.

Sample 41 (tableware): The sample had a very fine-grained matrix and the lithic fraction exhibited slightly greater packing than the two preceding fragments. The lithic granules, mostly quartzose, were oriented and contained large amounts of oxides. Again, a different production is apparent because even at the macroscopic level, the distinguishing features were quite striking: extremely thin walls, external black varnish and interior burnishing and engraved decorations on the rim. According to archaeologists, the piece was certainly not made for everyday use.

Sample 46 (amphora): The sample showed a medium-high concentration of inclusions, low sorting, and hiatal type granule distribution. The fine-grained matrix had embedded quartz and plagioclase crystals, large clinopyroxene crystals, some basalt fragments and subordinate clay clumps. The sherd had an external engobe.

\section{Kiln wastes}

As a result of the observations of the ceramic fabric (spatial distribution, size, shape, occurrence and composition of the different components of the paste; Whitbread 1995), it was possible to directly correlate Fabric 1 with sample II; Fabric 2 


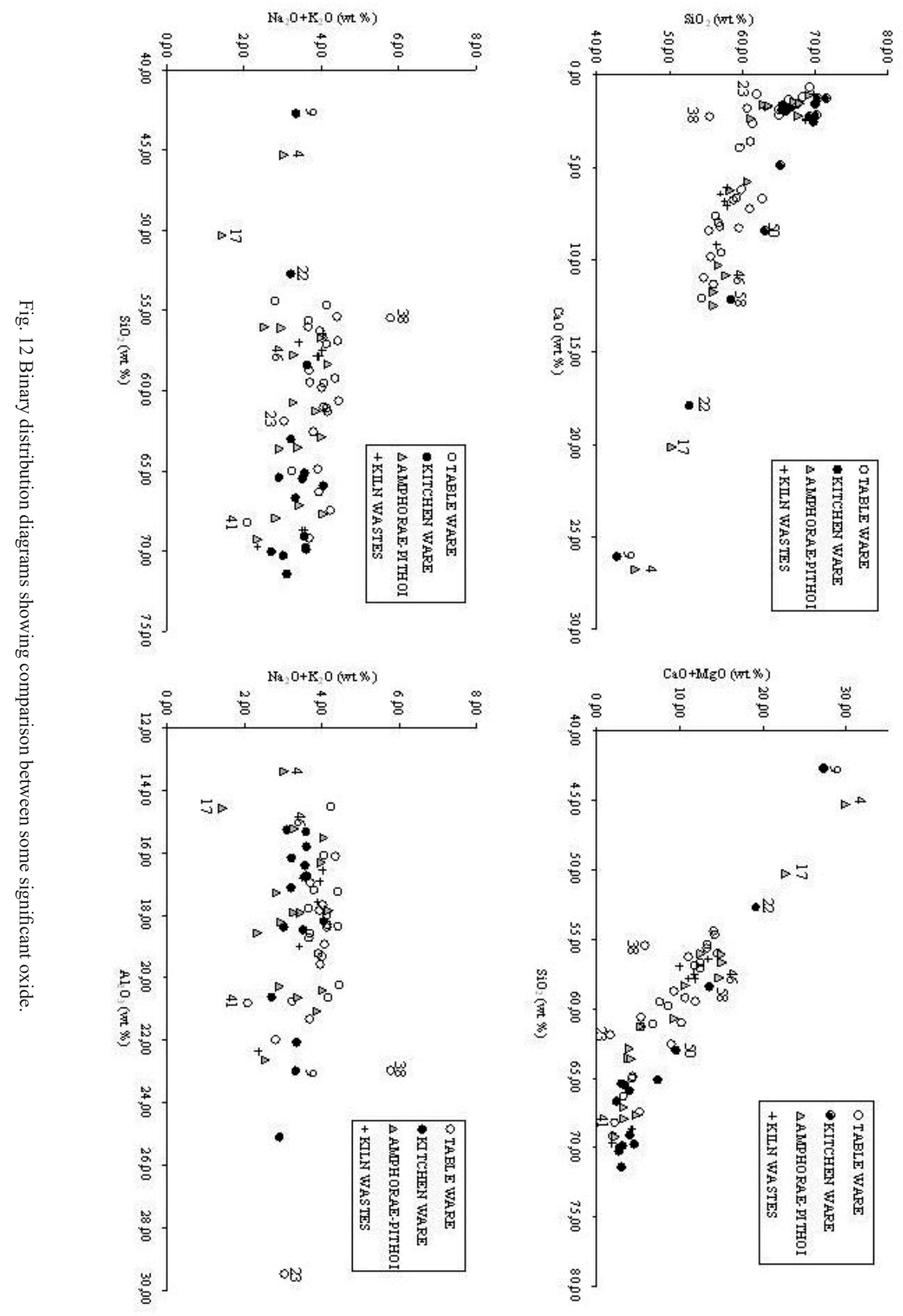




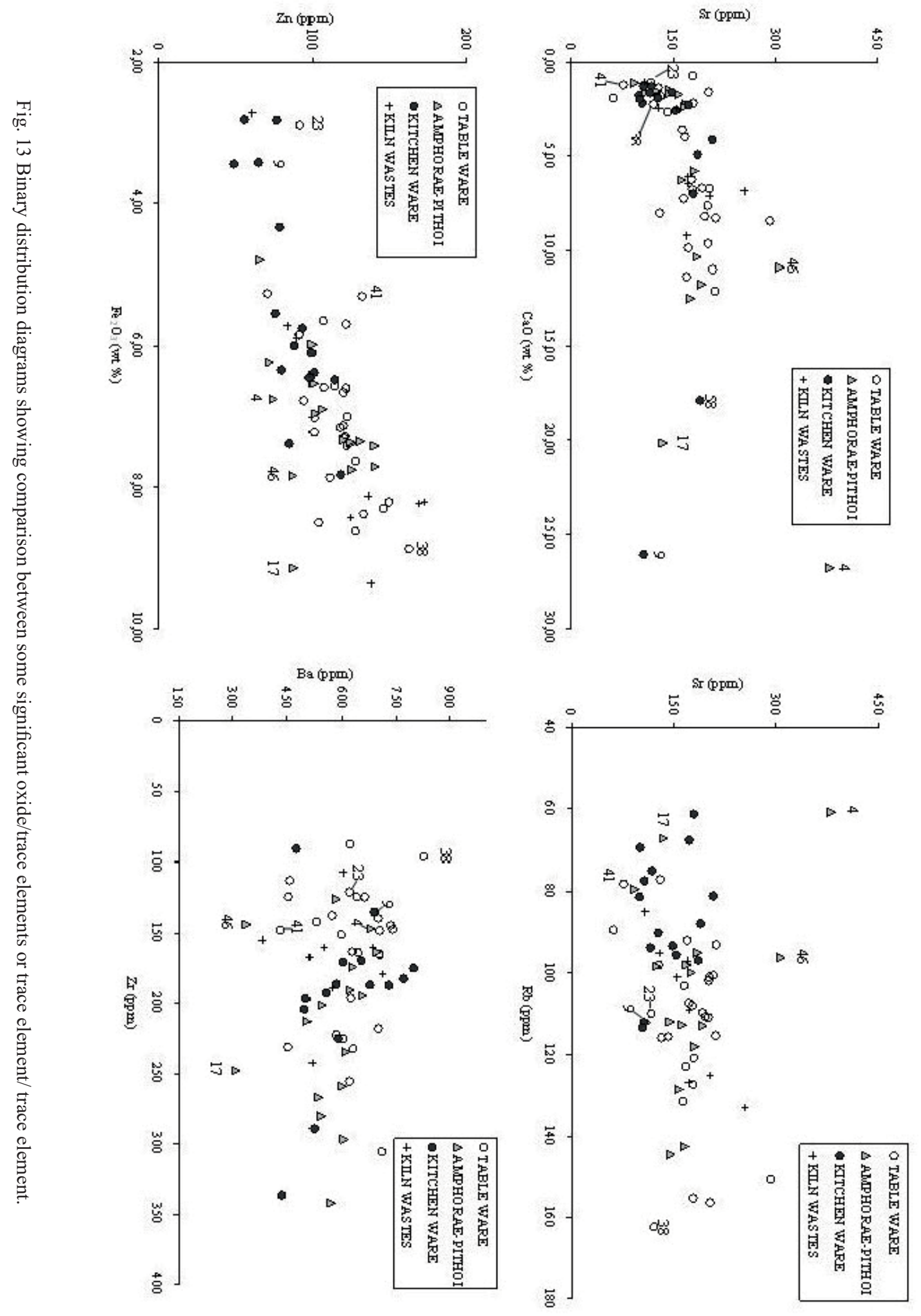


with samples I, III, IV, V and VIII; and Fabric 3A with samples VI and VII. Therefore, it could be concluded that these three fabrics were produced locally. Rare crystals of sericite were present in samples VI and VII.

\section{Clay}

The mineralogical composition of three of the four clays (AR1, AR2 and DR2) is homogeneous and consistent with that of most of the analysed samples (quartz, plagioclase, muscovite and K-feldspar; Fig. 10a-b, and rare crystals of sericite). Their granulometry is similar to Fabric 1 and 2, but only in AR2 were there frequent calcite crystals and fine rounded fragments of calcareous pellets (the same as those noted in Fabric 2; Fig. $10 \mathrm{c})$. There were scarce and very small $(<20 \mu \mathrm{m})$ neoformation oxides in the sample fired at $900{ }^{\circ} \mathrm{C}$.

The percentage of muscovite was lower in samples fired at higher temperatures, presumably due to the breakdown of the mineral at temperatures of around $900{ }^{\circ} \mathrm{C}$ (Mignucci 2002: 245-252; Rodriguez-Navarro et al. 2003: 713-724).

Besides the above-mentioned minerals, sample DR1 with coarser granulometry had inclusions of quartzose and shale metamorphic rocks and sporadic gastropod shells (Fig. 10c) of the same type as those found in the third ceramic group described above (Fabric 3B), but the shells had a finer granulometry (0.3-1 mm in Fabric 3B; max 0.2 $\mathrm{mm}$ in the clay sample). Also, this sample fired at $900{ }^{\circ} \mathrm{C}$, revealed neoformation oxides.

\section{PXRD analyses}

PXRD data almost always coincides with OM observations, except those cases where this type of analysis is able to detect low percentages of some mineralogical phases not noticeable under OM. The results are a semi-quantitative estimation of peak intensities.
Results (Table 2) indicate the constant presence of quartz, which is predominant in all samples, followed by feldspar, which varies from scarce to abundant.

The presence/absence of certain mineral phases confirmed the divisions made between the fabrics within the functional classes by the petrographic study with MO. For example, in samples characterised by Fabric 2 (tableware, amphorae-pithoi and kiln wastes), calcite was always detected in widely varying percentages, from traces to detectable quantities in 17 samples and from less abundant to abundant in six samples. However, in samples characterised by Fabric 1, this mineralogical phase was detectable in trace amounts at best.

In the kitchenware group, calcite was only detected in three samples $(22,50$ and 58) at levels from detectable to abundant, corresponding to Fabric 3B (with gastropods).

The abundance of mica, almost always present in the specimens studied, also varied widely (from absent to abundant) within the different fabrics identified. The authors note, however, a systematically higher frequency of micas in samples that contained more calcite, which reached a maximum firing temperature of $800{ }^{\circ} \mathrm{C}$. In addition, the amount of micas was lower in the kitchenware group than in other categories, with abundances ranging from scarce to absent.

Pyroxene was found in 40 specimens, and gehlenite was found in nine. Neither mineral phase was detected with the optical microscope because of the small grain size of these neoformation crystals. Two neoformation phases only appeared together in s. n. 14 and 59. Pyroxene was generally scarce to slightly abundant; gehlenite, which was generally found in small quantities, was more abundant in specimens 32 and 44 only.

Calcite was absent in 21 of the 40 samples containing pyroxene and gehlenite, while in the remainder it was found only in low quantities.

Gehlenite and pyroxene were often associated with appreciable quantities of iron oxides (hematite and magnetite; see Table 2). 
The diffractometric kiln wastes data highlighted the absence of gehlenite and iron oxides and once again confirmed the predominant presence of quartz and feldspar in all samples. Micas and calcite were detectable in those samples classified as Fabric 2 (I, III, IV and V).

In petrographic "singles", quartz was still the dominant phase; feldspar was abundant only in samples 38 and 46 and from poor to slight abundance in the others. Micas were always present in low quantities, except in sample 17, where it was absent. Calcite was the main mineral in samples 4,9 and 17 , while pyroxene was very abundant in sample 46 only. Gehlenite, found in small quantities in most samples, was more abundant in specimen 17.

Diffractometric analyses of clays as received and after firing at 600 and $900{ }^{\circ} \mathrm{C}$ (Table 3) confirmed the presence of most of the mineralogical phases revealed in the pottery fragments and kiln wastes (quartz, feldspar, mica, calcite, pyroxene, gehlenite and haematite) via PXRD.

The diffractograms of samples DR2, AR1 and AR2 both as received and after firing at $600{ }^{\circ} \mathrm{C}$, revealed amphibole and sericite in the first two and sericite, calcite and dolomite in the third sample, although they were always found in small quantities. Dolomite was not present in the ceramic fabrics deemed to be of local origin or in kiln wastes, whilst sericite was only present in four pottery samples and two kiln wastes. It should be noted that amphibole, sericite, mica, calcite and dolomite, while present after heating to $600{ }^{\circ} \mathrm{C}$, disappeared after the second firing at $900{ }^{\circ} \mathrm{C}$ (Fig. 11).

Gehlenite, pyroxene and hematite were formed on firing at $900{ }^{\circ} \mathrm{C}$ only in those samples that originally contained calcite and dolomite (AR2 and DR1; Fig. 11), although these phases appeared in the "embryonic" state (Peter and Iberg 1978: 503). Diffractometry also revealed a considerable reduction in the mica content of samples fired at $900^{\circ} \mathrm{C}$.

\section{XRF analyses}

The results of the chemical analysis using XRF are shown in Table 4.

To make the data more comparable with each other, the authors believed it useful to consider each value normalised to $100 \mathrm{wt} \%$ without LOI. In other words, each sample was recalculated as a total $(100 \mathrm{wt} \%)$ without LOI and the corresponding values of the individual oxides.

The data clearly shows that $\mathrm{SiO}_{2}, \mathrm{Al}_{2} \mathrm{O}_{3}, \mathrm{Fe}_{2} \mathrm{O}_{3}$ and $\mathrm{CaO}$ oxides were the major oxides (Table 4). $\mathrm{MgO}, \mathrm{Na}_{2} \mathrm{O}$ and $\mathrm{K}_{2} \mathrm{O}$ were the minor oxides that were highly variable and evidently unrelated, most likely because they are linked to the contributions of metamorphic materials in the mixtures. Chemical data less clearly allows for the same divisions of petrography within ceramic classes. The unclear separation among samples leads us to conclude that, probably, almost all the sherds share the same petrofacies (i.e. the same distinctive petrographical and mineralogical content).

However, as pertaining to petrographics, the presence/absence of $\mathrm{CaCO}_{3}$ showed a distinction between different fabrics in different pottery classes, so the chemical analysis of mainly calcium oxide confirmed that discrimination.

In the chart comparing $\mathrm{SiO}_{2}$ vs. $\mathrm{CaO}$ (Fig. 12a), almost all samples (except the four petrographic "singles": 4, 9, 17 and 38, and one kitchenware: 22) fall into two fairly distinct categories: a homogenous and narrow $\mathrm{CaO}<5 \mathrm{wt} \%$ and $\mathrm{CaO}$ $>5 \mathrm{wt} \%$.

The category of $\mathrm{CaO}<5 \mathrm{wt} \%$ covered most of the findings in the groups of amphorae-pithoi (corresponding to Fabric 1) and kitchenware (Fabric 3A), and was therefore characterised by clay Ca-poor and Si-rich materials (due to the addition of a quartzose component as a temper in the mixture, confirmed by MO).

Most of the samples of tableware (Fabric 2) fall into the category of $\mathrm{CaO}>5 \mathrm{wt} \%$, suggesting the use of different clay from previous materials, richer in $\mathrm{CaCO}_{3}$. Ten samples from the tableware 
group, however, that fall into the $\mathrm{CaO}<5 \mathrm{wt} \%$ category (Fabric 1) have a chemical behaviour obviously very similar to samples from the amphorae-pithoi class of the same fabric (Fabric 1), and also very similar to most of the samples of the class of kitchenware (Fabric 3A), albeit a very different grain size as observed in MO. This finding could suggest the use of the same clay from the same location, treated differently for the production of items that were functionally very different.

Another important fact to note is how the eight pieces that were certainly produced locally (kiln wastes) were distributed perfectly between two areas identified on a petrographic basis: samples I, III, IV, V and VIII have values entirely similar to those of the tableware group (Fabric 2; Table 7), while samples VI and VII show chemical data comparable to those of Fabric 1 (sample II) and the kitchenware group (Fabric 3A; Table 7).

Three of the seven petrographic "singles" (4, 9 and 17) fall far from the main distribution (see Fig. 12), thereby confirming their distinct nature, as already noted. Sample 22 seemed to have a different chemical nature compared with the rest of the group to which it belonged (kitchenware), but its position far from the main distribution solely depended on its high content of gastropods $\left(\mathrm{CaCO}_{3}\right)$, as noted in $\mathrm{OM}$. The petrographic "singles" 23, 41 and 46 always fell within the compositional fields of the other specimens (Fig. 12a-b-c), while 38 differed slightly from the two main compositional "clouds" (Fig. 12a-b-c). Only in the chart $\mathrm{Na}_{2} \mathrm{O}+\mathrm{K}_{2} \mathrm{O} v$ s. $\mathrm{SiO}_{2}$, did samples 23 and 38 deviate more from the main compositional "cloud".

The chemical data from samples 4, 9 and 17, in addition to the minero-petrographic observations and archaeological hypothesis (only samples 4 and 17), suggested a different production from what has been referred to as "local", confirming these objects as imports.

However, for samples 23, 38 and 41 (recognised as imports by archaeologists) the petrography suggests a different texture from that observed for most samples, but the lack of inclusions did not allow any assumptions to be made about the origin; thus, the chemical analysis clearly helped to include these samples into the group considered to be locally produced.

Finally, sample 46, which was characterised by a temper that was completely inconsistent with both local and regional geological data (Dimitriević 1997), cannot be considered to have been made locally, although it mainly falls within the compositional groups.

Trace elements showed greater dispersion (Fig. 13) than most of the major oxides, thereby contributing less to the analysis.

\section{DISCUSSION AND CONCLUSIONS}

The mineralogical and petrographic data allowed functional classes of 51/58 pottery samples to be classified into four different fabrics (Fabric $1,2,3 \mathrm{~A}$ and $3 \mathrm{~B})$.

This division is motivated by the observation of a greater diversity among the samples: the grain size, composition and the shape of the inclusions (Whitbread 1995).

Among the classes, the tableware and amphorae-pithoi were of Fabric 1 and 2. For this type of pottery, because the paste had a granulometry ranging from fine to very fine, the authors can assume the use of two different clays (more likely) or a different treatment during the production of the same functional class.

The first type of clay - Fabric 1 - was devoid of a carbonatic component and was enriched by a fine quartzose and metamorphic-quartzose component; this fabric was found in most of the amphorae-pithoi that were analysed, which were often large objects, requiring the use of coarser materials for their production.

The second type of clay used for Fabric 2 was characterised by the occurrence of scarce and very fine rounded fragments of calcareous pellets and calcite and by the absence of a fine metamor- 
phic-quartzose lithic component. With regard to the grain size from homogeneous to serial and the mostly rounded edges of the aplastic component, it indicated that either naturally 'pure' clay with fine granulometry was selected or that the clay was artificially purged of its coarsest component in order to prepare for the overall thin-walled vessels, i.e., tableware (Fig. 6).

For kitchenware production, the hypothesis was that one type of raw material was used, given that in two of the fabrics ( $3 \mathrm{~A}$ and $3 \mathrm{~B}$ ), the same mineralogical and lithic component, granulometry and structure were observed, with the only difference being the addition of pieces of gastropod shells evident in Fabric 3B. The finding that these anomalous inclusions were a naturally occurring component in one of the local clay samples (DR1) and were probably used as a raw material confirms the hypothesis of the autochthonous origin of the specimens. However, the granulometry and concentration of shells were much higher in the pottery (Fig. 8d) than in the clay, indicating the addition of extra quantities of this material, widely found at the archaeological site (Fig. 8e), to the paste during fabrication.

In the case of Fabric 3, the clay was enriched with an inert quartzose component with coarse, sharp-edged granulometry (mainly fragments of metamorphic- quartzose and schistose rocks, Fig. 8c) to make the paste more resistant to heat treatment. Many studies of the tempers used in fired ceramics (quartz, shells and calcite) have shown that ceramic pastes with calcareous inclusions are subjected to calcination $\left(\mathrm{T}>900^{\circ} \mathrm{C}\right)$ and the formation of new phases that increase the mechanical strength more than those with quartz additives (Tite et al., 2001), which then render the paste more refractory.

Based on their microscopic characteristics, seven of the specimens $(4,9,17,23,38,41$ and 46) could not be assigned to any of the three fabrics.

In particular, three of them (s. n. 23, 38 and 41 , recognised as forms unfamiliar to local tradi- tion) showed a number of distinct features in the matrix (highly purified), ascribable to a different method of production and choice of clay (Fig. 9) other than that of a non-local origin, which was confirmed by the chemical data (Fig. 12). In fact, apart from in Fig. 12d, samples 38 and 23 were outside of the uniform cloud. The interpretation of this data suggests the circulation and arrival of non-local styles and technologies to Viminacium, produced using local raw materials.

The remaining four $(4,9,17$ and 46) show a very different composition in both the model (Fig. 8) and chemical composition (Fig. 11). This data corroborates the hypothesis of the non-local origin of the amphorae (4, 17 and 46), which is in agreement with the archaeological data and suggests a non-local origin for the kitchenware sample number 9. Consequently, these objects were imports and were transported to Viminacium as finished goods.

By virtue of their fabric (spatial distribution, size, shape, occurrence and composition of the different components in the paste; Whitbread, 1995), the authors could directly correlate Fabric 1,2 and $3 \mathrm{~A}$ of the pottery samples with the kiln waste samples and thus assume local production of most of the pottery. The eight kiln wastes were classified as Fabric 1 (sample II), Fabric 2 (samples I, III, IV, V and VIII) and Fabric 3A (samples VI and VII).

\section{Provenance of raw materials}

There is good correspondence between the mineralogical and petrographic data of the inclusions (both naturally occurring and added to the paste) in all specimens (both the 51 pottery fragments and the eight kiln wastes), and those in the matrix of the locally available raw materials, suggesting the local production of most samples. From a petrographic perspective, nearly all the fabrics (1, 3A and 3B) contained metamorphic rock fragments (quartzose and micaceous schists), 
polycrystalline quartz, muscovite and, occasionally, sericite. These same components were found in two kiln wastes (VI and VII) and in the local clays (AR1, AR2 and DR2). In addition, two neoformation phases, gehlenite and pyroxene, which appeared in clay samples DR1 and AR2 after firing at $900^{\circ} \mathrm{C}$, were also found in the pottery specimens (Table 2).

Further evidence in favour of the local production of the objects is found in the evaluation (OM and PXRD) of the concentration of micas: they are present in medium amounts in the finegrained fabrics (1 and 2) and in higher amounts in the coarse-grained fabric (3A) in both the ceramics and kiln wastes, a sign of a different, albeit local, supply.

The types of inclusions observed in the pottery and clay specimens were in complete conformity with the outcropping lithotypes in the area surrounding the archaeological site. Metamorphic rocks appeared both on and below the surface approximately $10 \mathrm{~km} \mathrm{NE}$ of Viminacium near the settlement of Ram, with their mineralogical associations being similar to those of the samples that were studied (muscovite, sericite and quartz; Fig. 12). Their break-up would lead to the formation of the lithic inclusions constituting the clay of the sedimentary basin of the rivers Mlava and Danube. A second hypothesis concerns the direct provisioning by potters of such non-carbonate materials, which were used as temper and were most easily obtainable in terms of distance from the site, as there was an exclusive source of sedimentary rock within $10 \mathrm{~km}$ of Viminacium (Fig. 4a). Metamorphic quartzose boulders (Micaschist) were also found as part of amphitheatre in Viminacium, further indicating that this material was known and exploited at the time.

Data on major and trace elements confirmed the subdivisions defined according to petrographic evidence. The bivariate diagrams showed a main homogeneous group that contained most of the analyzed specimens, suggesting that they came from a single production area that was very probably local. The samples outside this "cloud" corresponded to three of the seven identified petrographic "singles" $(4,9$, and 17), confirming observations regarding their distinctive characteristics. For these samples, the authors can assume a non-local production (movement of finished goods), taking into account not only the chemical data, but also the composition of the skeleton observed microscopically (fossils for sample 4, and large sharp edged calcite and carbonate rocks fragments for samples 9 and 17).

It is worth noting that although petrographic "single" 46 does not fall sharply outside the main chemical group in the bivariate distribution, a local source of raw materials with volcanic fragments similar to those observed by microscopy is presently unknown, but it can't be excluded. This pottery could have been imported.

Instead, the technological and minero-petrographic characteristics of the three petrographic "singles" $(23,38$ and 41) point to an uncertain production, but chemical data for these samples generally fell just within the borders of the main "cloud" (Fig. 12). These samples were simply assumed to have undergone a different processing of local raw materials, which shows remarkable experience on the part of the workers responsible for a particular product (circulation of styles).

\section{Technological aspects}

Observations of the techniques used in the production of the ceramic paste also lent support to the same subdivision by composition.

All samples belonging to the fine-grained group (Fabric 1-2), except three amphorae (14, 35 and 47), a pithos (48) and five pieces of tableware $(26,28,34,42$ and 55), have a surface coating. The type of finish varied and may have been present on either one or both surfaces of the object. Where it was external, the layer had aesthetic and waterproofing functions (varnish, engobe, and burnishing). However, where it was 
internal, its main function was to conserve its contents (food), since this type of inner coating was found on objects of everyday use. Objects with an inner and an outer coating were generally important or valuable and probably had some particular significance apart from their everyday usefulness.

Most samples in the coarse-grained group (Fabric 3A-B) did not have external coatings (Table 1), as they were mainly articles used for cooking.

Technologically it is important to note the peculiarity in the cases of the amphorae $(2,5,6,14$, $16,18,35,44,45$ and 47) and the pithoi (30, 54 and 48), and was evident in the results of local production from the intersection of all analytical data. Their production was unusual because of the use of purified clay, with the addition of a small amount of a coarser quartzose component. Normally, objects of this type, given their size, have fabrics with a richer temper (Guerrini and Mancini 2007: 197-234).

Some of the samples referred to as petrographic "singles" by OM observation $(23,38$ and 41) provided evidence of a clearly different method of execution and a high level of technical skill and craftsmanship. Sample 38, the most finely worked and best preserved fragment (Fig. 7c), was a "terra sigillata" of red paste fired in a highly oxidising environment and then painted bright red. It was fashioned from highly purified clay containing rare, small clumps (Fig. 8d). The border bears a beautiful impressed decoration that is evidence of the most advanced technical level of any of the specimens. Also sample 41, which has highly refined technical and production characteristics - thin walls, internal and external coatings, extreme purification of the paste (Fig. 7d) and a high neoformation oxide content - was quite different from the remaining pottery studied here that was mostly for everyday use. A hypothesis can be advanced about their origin: the manufacturing might belong to a reproduction of forms and technologies imported into Viminacium, whereas their production, on the basis of chemical data, could be considered local.
The examined specimens include examples of ceramic firing in reducing or oxidising environments and those of simultaneous reduction and oxidisation. The choice of firing atmosphere, which is well-documented in literature, was linked not only to aesthetic function but also, in particular, to technical requirements. To maintain high temperatures in the kilns, which often burned for days on end, fuel had to be added occasionally (at any time during the firing). This produced smoke, thereby leading to a reduced amount of oxygen in the kiln, which gave rise to the black surface colour of the pottery (Cuomo Di Caprio 2007). It seems that only for articles of a certain value did the potters pay careful attention to controlling the firing atmosphere in order to obtain homogeneous colours in the bisque.

The firing temperatures for most of the fragments believed to be of local origin, especially the fine-grained ones (Fabric 1-2), must have reached at least $850-900{ }^{\circ} \mathrm{C}$ and up to $1,050{ }^{\circ} \mathrm{C}$, as neoformation mineralogical phases, such as gehlenite, pyroxene and iron oxides were generated (Capel et al. 1985:563-575; Duminuco et al. 1996: 281288; Ricciardi et al. 1999:393-409; Cultrone et al. 2001:621-634).

The sericite, amphibole, dolomite and calcite in the clays fired at $600{ }^{\circ} \mathrm{C}$ were not present in the pottery specimens (see Table 2) or kiln discards, probably because they were fired at a temperature exceeding $600{ }^{\circ} \mathrm{C}$; in fact, these phases disappeared in the cooking tests on clays at $900{ }^{\circ} \mathrm{C}$.

Another aspect that suggests very high firing temperatures is the absence of birefringence in the specimen matrices, indicating the complete decomposition of clay minerals and further attesting to firing temperatures well above $800{ }^{\circ} \mathrm{C}$ (Brisbane, 1981). There are few cases in which the ceramics were low-fired, as evidenced by the finding of a less birefringent black core in comparison to a more birefringent brown-orange border.

However, for the kitchenware group, the firing temperatures were estimated to be slightly lower. The almost total absence of gehlenite assumes a 
firing temperatures not exceeding $850^{\circ} \mathrm{C}$; the absence of iron oxides, the medium-high presence of muscovite, the high presence of gastropods (Fabric 3B) and the low presence of pyroxene suggest a temperature reaching around $900{ }^{\circ} \mathrm{C}$ (Cultrone et al. 2001; Rodriguez-Navarro et al. 2003: 713-724).

Comparing the results of the firing tests of raw materials, it may be concluded that pyroxene and gehlenite were formed by the complete thermal decomposition of calcite and the reaction of calcium oxide with the molecular fractions of clay or quartzose minerals. Calcite was absent in most samples (27 out of 43) containing pyroxene and gehlenite, which provides evidence for the formation of these two phases at the expense of calcite and silicate phases as precursors.

When calcite was present contemporaneously with neoformation phases, it was predominantly secondary and due to contamination during burial as evidenced by microscopic observations (Cau et al. 2002: 9-18). Sericite, present in three of the four clay samples fired at $600{ }^{\circ} \mathrm{C}$ (AR1, AR2 and DR2), four of the 58 pottery specimens $(21,22$, 35 and 40), and two of the eight kiln wastes (VI and VII) indicated lower firing temperatures (no higher than $700{ }^{\circ} \mathrm{C}$; Mignucci 2002: 245). This mineral probably originates from the breakdown of the nucleus of metamorphic rocks occurring a few kilometres from Viminacium (see geological sketch-map, Fig. 4a-b). It was not found in any of the other samples believed to be local because the firing temperatures were evidently above $700{ }^{\circ} \mathrm{C}$.

Lastly, the structural characteristics found in most of the specimen fabrics indicated a high degree of sintering; the use of non-calcareous temper, despite the wide availability of such materials in the old city, indicates a good knowledge of local sources by ancient potters. Both of these aspects constitute a good technological choice for preventing the breakdown of $\mathrm{CaO}$ and enhancing the thermal resistance of the pottery (Heimann 1989: 123-148; Tite et al. 2001: 301-324).

A future comparison of this archaeometric data with those of studies made on pottery of the same historical period (from the second half of the 2nd century to the end of the 3rd century), reproduced at various sites of the Roman Empire, will help to define the extent of expertise within the context of a very large Empire, and will provide the ability to render a vast territory that, from a technological viewpoint, extended from Gibraltar to the borders with Mesopotamia, homogenous.

\section{ACKNOWLEDGEMENTS}

Special thanks to Prof. G. Montana for his availability, invaluable advice and the time he gave whenever asked for his expert opinion. Further thanks go to Dr. Snezana Nikolic for allowing us to sample materials, Prof. E. M. Azzaro for conducting chemical analyses, Prof. J. Pignatti for paleontological recognition, Prof. L. Lezzerini for providing language assistance and Mr. S. Stellino for his assistance in the XRD laboratory.

\section{BIBLIOGRAPHY}

\section{Brisbane, M. A. 1981}

Incipient markets for early Anglo-Saxon ceramics: variation in levels and modes of production. Production and Distribution: A Ceramic Viewpoint, eds. H. Howard and E. Morris, International Series 120. Oxford: British Archaeological Reports: $229-242$.

\section{Capel, J., Huertas, F. and Linares, J. 1985}

High temperature reaction and use of Bronze Age pottery from La Mancha, central Spain. Mineralogica Petrographica Acta, 29 A: 563-575.

\section{Cau Ontiveros, M. A., Day P. M. and Montana, G. 2002}

Secondary calcite in archaeological ceramics: evaluation of alteration and contamination processes by thin section study. Modern Trends in Scientific Studies on Ancient Ceramics, Oxford: 
BAR International Series 1011: 9-18.

Cultrone, G., Rodriguez-Navarro, C., Sebastian E., Cazalla, O. and De la Torre, M. J. 2001

Carbonate and silicate phase reactions during ceramic firing. European Journal of Mineralogy, 13: 621-634.

\section{Cuomo di Caprio, N. and Vaughan, S. 1993}

An experimental study in distinguishing grog (chamotte) from argillaceous inclusions in ceramic thin sections, Archaeomaterials 7: 21-40.

\section{Cuomo di Caprio, N. 2007}

La ceramica in archeologia Vol. 2. Antiche tecniche di lavorazione e moderni metodi di indagine. L'Erma di Bretschneider.

\section{Dimitrijević, M. D. 1997}

Geology of Yugoslavia. Republical Foundation for Geological Investigations and Geological Institute GEMINI.

Duminuco, P., Riccardi, M. P., Messiga, B. and Setti, M. 1996

Modificazioni tessiturali e mineralogiche come indicatori della dinamica del processo di cottura di manufatti ceramici, Ceramurgia 26, 5: 281-288.

\section{Franzini, M., Leoni L. and Saitta, M. 1975}

Revisione di una metodologi analitica per fluorescenza-X, basata sulla correzione completa degli effetti di matrice, Rend. Soc. It. Min. Petrol. 31: 365-378.

\section{Guerrini, C. and Mancini, L. 2007}

La ceramica di età romana. Introduzione allo studio della ceramica in archeologia, Siena: 197234.

\section{Heimann, R. B. 1989}

Assessing the technology of ancient pottery: the use of ceramic phase diagrams, Archaeomaterials 3: 123-148.

\section{Korać, M. 2006}

Reč urednika, Arheologija i prirodne nauke 1: 7-9.

\section{Kretz, R. 1983}

Symbols for rock-forming minerals, American Mineralogist 68: 277-279.

\section{Leoni, L. and Saitta, M. 1976}

X-Ray fluorescence analysis of trace elements in rock and mineral standards, Rend. Soc. Ital. Min. Petrol. 32: 497-510.

\section{Maggetti, M. 1982}

Phase Analysis and its Significance for Technology and Origin, Archaeological Ceramics, Washington: Smithsonian Institution: 121-133.

\section{Mignucci, A. 2002}

The 13th-14th century Venetian ceramic production of "Graffita a spirale-cerchio", "Graffita S. Bartolo" and Glazed Ceramic: a new reference group and an attribution. Modern Trends in Scientific Studies on Ancient Ceramics, Papers presented at the 5th European Meeting on Ancient Ceramics, Athens 1999, eds. V. Kilikoglou, A. Hein and Y. Maniatis, Oxford: BAR International Series 1011: 245-252.

\section{Peters, T. J. and Iberg, R. 1978}

Mineralogical changes during firing of calcium-rich brick clays, Am. Ceram. Soc. Bull. 57: 503.

\section{Raičković, A. i Redžić, S. 2006}

Keramičarske i opekarske peći Viminacijuma lokacije Pećine i Livade kod Ćuprije, Arheologija i prirodne nauke 1: 81-106.

\section{Raičković, A., Redžić, S. i Rogić, D. 2006a}

Terakote sa prostora zanatskog centra Viminacijum, Arheologija i prirodne nauke 2: 77-86. 
Raičković, A., Redžić, S. i Milovanović, B 2006b

Posude sa apliciranim zmijama iz zanatskog centra sa Viminacijuma, Arheologija i prirodne nauke 2: 69-76.

\section{Raičković, A. 2007}

Keramičke posude Zanatskog centra iz Viminacijuma, Beograd: Centar za nove tehnologije.

Raičković, A. i Vuković, S. 2009

Keramičarska peć sa istočne nekropole Viminacijuma, Arheologija i prirodne nauke 4: 7-15.

\section{Raičković, A. i Milovanović, B. 2009}

Rezultati istraživanja jugozapadnog dela lokaliteta Pirivoj (Viminacijum), Arheologija i prirodne nauke 5: 7-56.

Ricciardi, M.P., Messiga, B. and Duminuco, P. 1999

An approach to the dynamics of clay firing, $A p$ plied Clay Science 15: 393-409.

Rodriguez-Navarro, C., Cultrone, G., Sanchez-Navas, A. and Sebastian, E. 2003

TEM study of mullite growt after muscovite break down, American Mineralogist 88: 713-724.

Tite, M. S., Kilikoglou, V. and Verkinis, G. 2001 Strength, toughness and thermal shock resistance of ancient ceramics, and their influence on technological choice, Archaeometry 43(3): 301-324.

\section{Walton, M. S. 2010}

Production technology of Roman lead-glazed pottery and its continuance into late antiquity, $\mathrm{Ar}$ chaeometry 52: 733-759.

\section{Whitbread, I. K. 1986}

The characterisation of argillaceous inclusions in ceramic thin sections, Archaeometry 28, 1: 79-88.

\section{REZIME}

\section{RIMSKA KERAMIKA IZ VIMINACIJUMA (SRBIJA II-III VEK NOVE ERE): KARAKTERISTIKE MINEROLOŠKOG SASTAVA, PROIZVODNJA I TEHNOLOŠKI ASPEKT}

\section{KLJUČNE REČI: ARHEOMETRIJA, KERAMI- KA, RIMSKI PERIOD, VIMINACIJUM.}

Rad je rezultat više analiza koje su izvršene nad šezdesetak uzoraka fragmenata keramičkih posuda, sirove gline, kao i gline od koje su napravljene opekarske peći iz zanatskog centra na Viminacijumu.

Cilj je bio stvaranje referentne hemijske i minerološko petrografske celine sa kojom bi se potom mogli porediti ostali keramički uzorci. Dobijeni rezultati su nam dali informacije ne samo o tome na kojoj temperaturi su posude pečene (koja je temperatura dostizana u opekarskim pećima) nego i o tome kakav je kvalitet korišćene gline, koji su najčešći dodaci glini i u kojim odnosima korišćeni. Izdvaja se nekoliko grupa posuda u odnosu na to na kojoj su temperaturi pečene, a samim tim i njihova čvrstoća je različita. Sve se nalaze u rasponu od 650 do $1050 \mathrm{C}^{\circ}$.

Minerološko petrografska analiza omogućila je podelu keramike na četiri grupe različitih struktura. Izvršena je na osnovu različitosti u veličini i izgledu čestica koji čine gline uzorka. Rezultat je, da iako su istog osnovnog sastava (glina istog porekla) u nekima je koncentracija granulata tolika da se ne može smatrati slučajnom, nego se radi o namernom obogaćivanju inertnim kvar- 
toznim komponentama, u ovom slučaju škriljcima. Kada se pogledaju uzorci kod kojih je ovo primećeno jasno se izdvajaju posude koje su korišćene za pripremu hrane i kao takve izlagane većim temperaturama. Eksperimenti su pokazali da se dodavanjem ove primese dobijaju posude koje bolje podnose i zadržavaju temperaturu.

Iste analize su otkrile i fragmente čije je poreklo sasvim sigurno van šireg areala Viminacijuma, a to ukazuje na trgovinu i import keramičkim materijalom.

Rezultati hemijskih analiza dati su na tabli br. 4. Oni pokazuju da su najčeši oksidi $\mathrm{SiO} 2, \mathrm{Al} 2 \mathrm{O} 3$ i $\mathrm{FeO} 3$, te da skoro svi fragmenti imaju taj isti petrografski i minerološki sadržaj, a da se veliko odstupanje vidi po pitanju $\mathrm{CaCO} 3$ što je prikazano na grafikonima. Ovo dokazuje da iako su u osnovi korišćene iste gline, one su predtretirane kako bi se od njih napravile funkcionalno različite posude. Isto tako, iskočili su i singlovi (fragmenti koji ne odgovaraju regionalnim geološkim podacima) koji pokazuju posude za koje se i inače smatralo da su stigle putem importa.

Ono što je bitno je da se ovi arheometrijski podaci mogu upoređivati sa drugima uzorcima na keramici istog perioda širom Rimskog Carstva i time proširiti dosadašnja saznanja o samoj tehnologiji izrade kao i o distribuciji posuda. 
Table 1

\begin{tabular}{|c|c|c|c|c|c|c|c|}
\hline Sample & Type & Fabric & Coating & Sample & Type & Fabric & Coating \\
\hline 20 & tableware & 1 & glaze & 29 & kitchenware & $3 \mathrm{~A}$ & absent \\
\hline 24 & tableware & 1 & painting & 43 & kitchenware & $3 \mathrm{~A}$ & absent \\
\hline 26 & tableware & 1 & absent & 53 & kitchenware & $3 \mathrm{~A}$ & absent \\
\hline 37 & tableware & 1 & painting & 56 & kitchenware & $3 \mathrm{~A}$ & absent \\
\hline 42 & tableware & 1 & absent & 57 & kitchenware & $3 \mathrm{~A}$ & absent \\
\hline 52 & tableware & 1 & engobe & 22 & kitchenware & $3 \mathrm{~B}$ & absent \\
\hline 55 & tableware & 1 & absent & 50 & kitchenware & $3 \mathrm{~B}$ & absent \\
\hline 60 & tableware & 1 & painting & 58 & kitchenware & $3 \mathrm{~B}$ & absent \\
\hline 1 & tableware & 2 & engobe & 9 & kitchenware & single & absent \\
\hline 3 & tableware & 2 & varnish & 2 & amphora & 1 & burnishing \\
\hline 7 & tableware & 2 & engobe & 5 & amphora & 1 & engobe \\
\hline 11 & tableware & 2 & painting & 14 & amphora & 1 & absent \\
\hline 12 & tableware & 2 & varnish & 47 & amphora & 1 & absent \\
\hline 15 & tableware & 2 & absent & 30 & pithos & 1 & engobe \\
\hline 28 & tableware & 2 & absent & 33 & pithos & 1 & absent \\
\hline 31 & tableware & 2 & painting & 48 & pithos & 1 & absent \\
\hline 32 & tableware & 2 & engobe & 54 & pithos & 1 & bunrishing \\
\hline 34 & tableware & 2 & absent & 6 & amphora & 2 & painting \\
\hline 36 & tableware & 2 & painting & 16 & amphora & 2 & engobe \\
\hline 39 & tableware & 2 & painting & 18 & amphora & 2 & engobe \\
\hline 40 & tableware & 2 & painting & 35 & amphora & 2 & absent \\
\hline 49 & tableware & 2 & painting & 44 & amphora & 2 & engobe \\
\hline 51 & tableware & 2 & varnish & 4 & amphora & single & absent \\
\hline 59 & tableware & 2 & painting & 17 & amphora & single & absent \\
\hline 23 & tableware & single & absent & 46 & amphora & single & engobe \\
\hline 38 & tableware & single & painting & II & kiln waste & 1 & engobe \\
\hline 41 & tableware & single & varnish & I & kiln waste & 2 & engobe \\
\hline 8 & kitchenware & $3 \mathrm{~A}$ & absent & III & kiln waste & 2 & engobe \\
\hline 10 & kitchenware & $3 \mathrm{~A}$ & absent & IV & kiln waste & 2 & painting \\
\hline 13 & kitchenware & $3 \mathrm{~A}$ & absent & V & kiln waste & 2 & absent \\
\hline 21 & kitchenware & $3 \mathrm{~A}$ & burnishing & VIII & kiln waste & 2 & engobe \\
\hline 25 & kitchenware & $3 \mathrm{~A}$ & engobe & VI & kiln waste & $3 \mathrm{~A}$ & engobe \\
\hline 27 & kitchenware & $3 \mathrm{~A}$ & absent & VII & kiln waste & $3 \mathrm{~A}$ & engobe \\
\hline
\end{tabular}

Table 1 The type, fabric and coating of the ceramic artefacts analysed. 
Table 2

Legend: Qtz, quartz; Feld, feldspar; Mca, mica; Cal calcite; Px pyroxene; Gh gehlenite; Ox haematite-magnetite; Ser sericite. (symbols as in Kretz, 1983). / absent; tr traces; + detectable; ++ not much abundant; +++ abundant; ++++ predominant. T tablewares; $\mathrm{A} / \mathrm{P}$ amphorae/pithos; $\mathrm{K}$ kitchenwares; $\mathrm{W}$ kiln wastes.

\begin{tabular}{|c|c|c|c|c|c|c|c|c|c|c|}
\hline \multicolumn{3}{|c|}{ Samples } & $Q t z$ & Feld & Mca & Cal & $P x$ & $\overline{G h}$ & $O x$ & $\overline{\mathrm{Ser}}$ \\
\hline \multirow{17}{*}{ 巻 } & \multirow{8}{*}{$\mathbf{T}$} & 20 & ++++ & + & 7 & 7 & $\operatorname{tr}$ & 7 & 7 & 7 \\
\hline & & 24 & ++++ & + & ++ & $\operatorname{tr}$ & / & / & 1 & 1 \\
\hline & & 26 & ++++ & ++ & / & / & $\operatorname{tr}$ & / & + & / \\
\hline & & 37 & ++++ & H & + & + & + & / & $\operatorname{tr}$ & / \\
\hline & & 42 & ++++ & + & $\operatorname{tr}$ & / & $\operatorname{tr}$ & 1 & + & / \\
\hline & & 52 & ++++ & + & + & / & + & / & + & / \\
\hline & & 55 & ++++ & + & + & / & $\operatorname{tr}$ & / & $\operatorname{tr}$ & / \\
\hline & & 60 & ++++ & + & / & 1 & H & 1 & + & / \\
\hline & \multirow{8}{*}{$\mathbf{A} / \mathbf{P}$} & 2 & ++++ & +1 & $\operatorname{tr}$ & / & $\operatorname{tr}$ & / & 1 & $/$ \\
\hline & & 5 & ++++ & + & + & / & $\operatorname{tr}$ & $\operatorname{tr}$ & $\operatorname{tr}$ & / \\
\hline & & 14 & ++++ & + & / & / & $\operatorname{tr}$ & $\operatorname{tr}$ & $\operatorname{tr}$ & / \\
\hline & & 30 & ++++ & + & + & / & $\operatorname{tr}$ & / & $\operatorname{tr}$ & / \\
\hline & & 33 & ++++ & ++ & 1 & I & + & $\operatorname{tr}$ & $\operatorname{tr}$ & / \\
\hline & & 47 & ++++ & + & + & / & $\operatorname{tr}$ & / & I & / \\
\hline & & 48 & ++++ & + & $\operatorname{tr}$ & $\operatorname{tr}$ & / & $\operatorname{tr}$ & $\operatorname{tr}$ & / \\
\hline & & 54 & ++++ & H+ & ++ & $\operatorname{tr}$ & / & / & / & / \\
\hline & W & II & +++ & +1 & 1 & 1 & + & 1 & 1 & $/$ \\
\hline \multirow{16}{*}{$\underset{\sim}{2}$} & \multirow{16}{*}{$\mathbf{T}$} & 1 & ++++ & +1 & + & $\operatorname{tr}$ & + & 1 & $\operatorname{tr}$ & $/$ \\
\hline & & 3 & ++++ & + & ++ & +++ & 1 & / & / & / \\
\hline & & 7 & ++++ & +++ & +++ & $\operatorname{tr}$ & + & / & + & / \\
\hline & & 11 & ++++ & + & ++ & ++ & $\operatorname{tr}$ & / & / & / \\
\hline & & 12 & ++++ & + & $\operatorname{tr}$ & $\operatorname{tr}$ & + & / & / & / \\
\hline & & 15 & ++++ & + & ++ & +++ & + & / & / & / \\
\hline & & 28 & ++++ & ++ & ++ & + & / & / & / & / \\
\hline & & 31 & ++++ & + & + & $\operatorname{tr}$ & $\operatorname{tr}$ & / & / & / \\
\hline & & 32 & ++++ & + & $\operatorname{tr}$ & ++ & / & ++ & + & / \\
\hline & & 34 & ++++ & +++ & + & + & / & / & $\operatorname{tr}$ & / \\
\hline & & 36 & ++++ & H & + & $\operatorname{tr}$ & + & / & $\operatorname{tr}$ & / \\
\hline & & 39 & ++++ & ++ & $\operatorname{tr}$ & + & + & / & + & / \\
\hline & & 40 & ++++ & + & ++ & +++ & / & / & + & $\operatorname{tr}$ \\
\hline & & 49 & ++++ & + & + & + & / & / & $\operatorname{tr}$ & / \\
\hline & & 51 & ++++ & +++ & / & $\operatorname{tr}$ & + & / & $\operatorname{tr}$ & / \\
\hline & & 59 & ++++ & $+H$ & $\operatorname{tr}$ & H & + & + & $\operatorname{tr}$ & / \\
\hline
\end{tabular}

Table 2 Mineralogical composition of archaeological specimens, by PXRD analysis. 


\begin{tabular}{|c|c|c|c|c|c|c|c|c|c|c|}
\hline \multicolumn{3}{|c|}{ Samples } & $Q t z$ & Feld & Mca & Cal & $P x$ & $G h$ & $O x$ & Ser \\
\hline \multirow{10}{*}{$\underset{n}{2}$} & \multirow{5}{*}{$\mathbf{A} / \mathbf{P}$} & 6 & +1++ & ++ & + & + & + & / & $\operatorname{tr}$ & / \\
\hline & & 16 & ++1+ & ++ & $\operatorname{tr}$ & + & + & / & / & / \\
\hline & & 18 & ++++ & ++ & $\operatorname{tr}$ & + & + & / & / & / \\
\hline & & 35 & ++++ & ++ & + & ++ & + & I & 1 & + \\
\hline & & 44 & $+1++$ & ++ & + & ++ & 1 & ++ & + & / \\
\hline & \multirow{5}{*}{ W } & I & ++++ & +++ & + & + & / & / & / & / \\
\hline & & III & +++ & + & + & + & / & / & I & I \\
\hline & & IV & ++1+ & +++ & + & + & $\operatorname{tr}$ & / & / & $/$ \\
\hline & & V & +++ & + & + & + & / & / & / & / \\
\hline & & VIII & +++ & + & / & + & $\operatorname{tr}$ & / & / & / \\
\hline \multirow{13}{*}{$\underset{2}{2}$} & \multirow{11}{*}{$\mathbf{K}$} & 8 & ++++ & ++ & / & / & + & / & / & / \\
\hline & & 10 & ++++ & $\operatorname{tr}$ & 1 & I & $\operatorname{tr}$ & / & / & / \\
\hline & & 13 & ++++ & + & $\operatorname{tr}$ & / & $\operatorname{tr}$ & / & / & / \\
\hline & & 21 & +H+ & +++ & $\operatorname{tr}$ & / & / & / & / & $\operatorname{tr}$ \\
\hline & & 25 & +1++ & + & / & I & / & / & / & I \\
\hline & & 27 & ++1+ & ++ & $\operatorname{tr}$ & / & $\operatorname{tr}$ & / & / & / \\
\hline & & 29 & ++++ & ++ & / & / & $\operatorname{tr}$ & / & / & / \\
\hline & & 43 & +H++ & +++ & $\operatorname{tr}$ & / & $\operatorname{tr}$ & / & / & I \\
\hline & & 53 & ++++ & +++ & $\operatorname{tr}$ & $\operatorname{tr}$ & + & 1 & 1 & 1 \\
\hline & & 56 & ++++ & ++ & I & / & $\operatorname{tr}$ & / & / & / \\
\hline & & 57 & ++++ & + & + & / & / & / & / & / \\
\hline & \multirow{2}{*}{$\mathbf{W}$} & VI & ++++ & +++ & / & 1 & 1 & 1 & 1 & $\operatorname{tr}$ \\
\hline & & VII & +++ & +++ & 1 & I & + & 1 & / & tr \\
\hline \multirow{3}{*}{$\stackrel{\omega}{\sigma}$} & \multirow{3}{*}{$\mathbf{K}$} & 22 & +H++ & ++ & + & +++ & / & $\operatorname{tr}$ & / & $\operatorname{tr}$ \\
\hline & & 50 & +H+ & ++ & $\operatorname{tr}$ & + & / & / & / & / \\
\hline & & 58 & +H++ & ++ & + & +++ & / & / & / & 1 \\
\hline \multirow{7}{*}{$\stackrel{\Omega}{\Omega}$} & \multirow{3}{*}{$\mathbf{T}$} & 23 & $+1++$ & $\operatorname{tr}$ & $\operatorname{tr}$ & / & / & / & / & / \\
\hline & & 38 & ++++ & +++ & + & $\operatorname{tr}$ & + & / & ++ & I \\
\hline & & 41 & ++++ & $\operatorname{tr}$ & $\operatorname{tr}$ & 1 & 1 & $\operatorname{tr}$ & / & / \\
\hline & $\mathbf{K}$ & 9 & +++ & $\operatorname{tr}$ & + & ++++ & / & $\operatorname{tr}$ & / & / \\
\hline & \multirow{3}{*}{$\mathbf{A} / \mathbf{P}$} & 4 & +++ & + & $\operatorname{tr}$ & ++++ & I & I & $\operatorname{tr}$ & 1 \\
\hline & & 17 & ++++ & + & / & +++ & / & ++ & / & / \\
\hline & & 46 & ++++ & +++ & $\operatorname{tr}$ & / & +++ & $/$ & + & / \\
\hline
\end{tabular}

Table 2 Mineralogical composition of archaeological specimens, by PXRD analysis. 


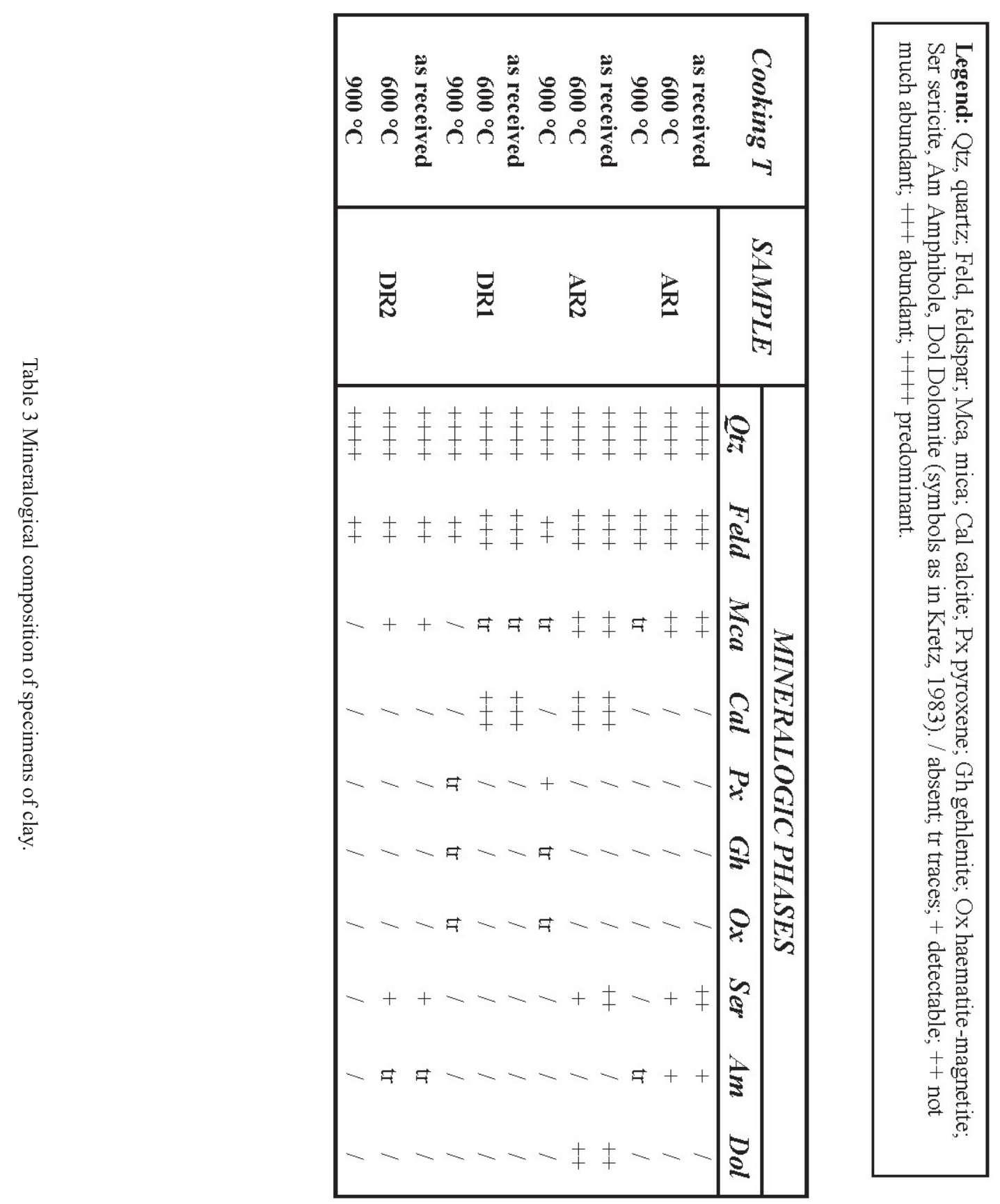




\begin{tabular}{|c|c|c|c|}
\hline 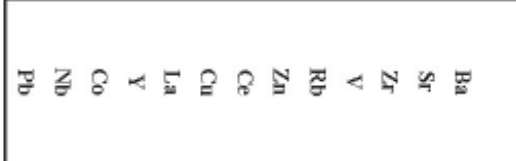 & 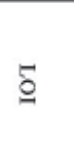 & 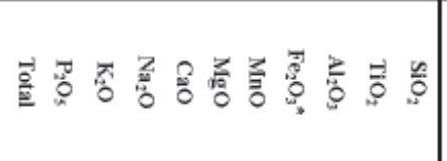 & 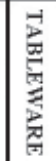 \\
\hline & & 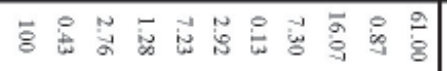 & - \\
\hline$\stackrel{2}{\circ}$ & $\infty$ & 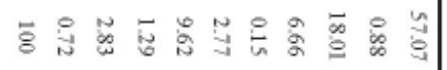 & $\omega$ \\
\hline $7-n+\omega=\bar{a}=$ & 悹 & 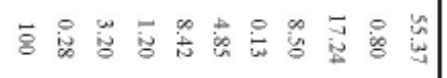 & - \\
\hline$--\omega+z=$ & $\ddot{\xi}$ & 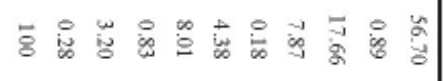 & $=$ \\
\hline 芯䃼 & d & $\overrightarrow{8}$ & is \\
\hline 录 & & 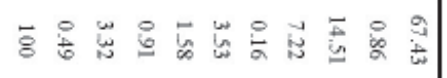 & का \\
\hline 究 & ?. & $\overrightarrow{8}$ & 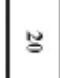 \\
\hline & & 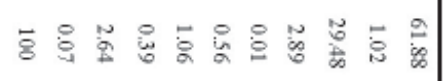 & 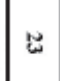 \\
\hline & & 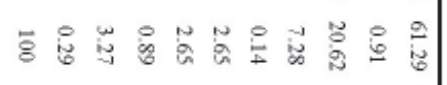 & 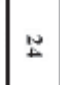 \\
\hline : : & $=$ & 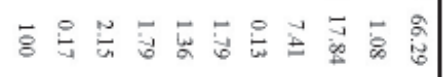 & $\%$ \\
\hline 宅 & $\ddot{z}$ & $\overrightarrow{8}+\frac{0}{4}$ & $\mathbb{\infty}$ \\
\hline & $\stackrel{s}{\infty}$ & 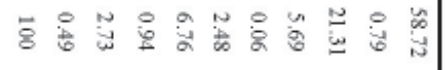 & 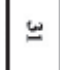 \\
\hline 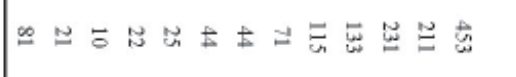 & $\stackrel{8}{=}$ & 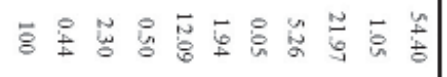 & is \\
\hline & $\therefore$ & 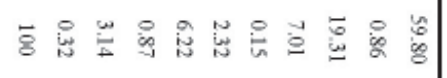 & $\Psi$ \\
\hline & 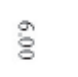 & 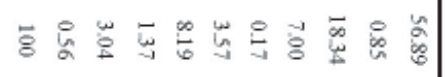 & 岕 \\
\hline 逭 & $=$ & 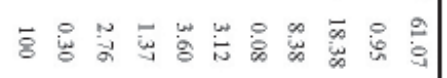 & 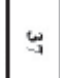 \\
\hline in & u & 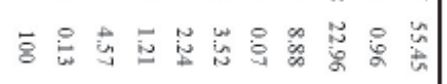 & $\mathscr{\infty}$ \\
\hline$\frac{8}{8}$ & & 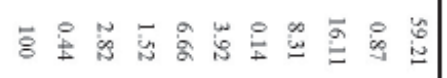 & : \\
\hline & & 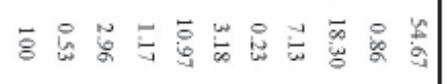 & t \\
\hline & 5 & 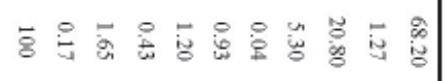 & $=$ \\
\hline & $\bar{\Phi}$ & 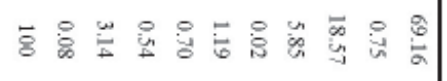 & is \\
\hline 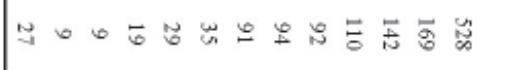 & $\stackrel{\infty}{0}$ & 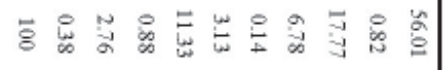 & t \\
\hline 空考 & $\stackrel{\infty}{\Theta}$ & 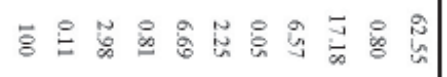 & 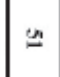 \\
\hline 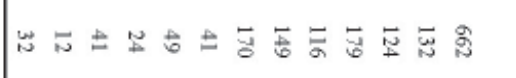 & $\ddot{\mathscr{\infty}}$ & $\overrightarrow{8}$ & is \\
\hline 迢可的莳崖古 & 勿 & $\overrightarrow{8}$ & 络 \\
\hline$\simeq \mp$ & 范 & 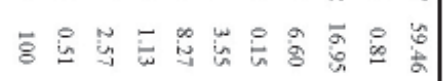 & is \\
\hline 果的 & $\tilde{s}$ & 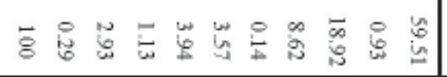 & : \\
\hline$\overline{\mathrm{z}}$ & & 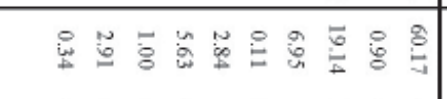 & \\
\hline & & & \\
\hline
\end{tabular}




\begin{tabular}{|c|c|c|c|}
\hline Z & & 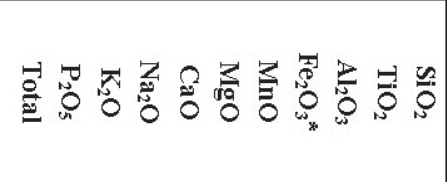 & 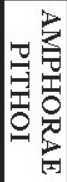 \\
\hline w & & 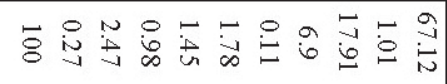 & N \\
\hline 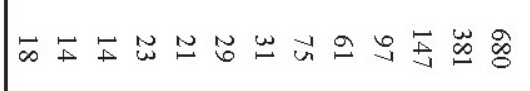 & $\alpha$ & 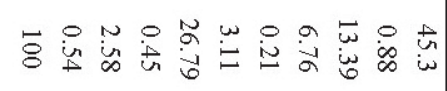 & 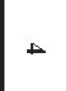 \\
\hline 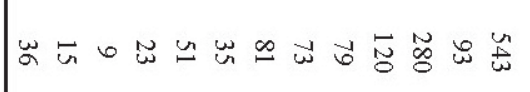 & $\stackrel{s}{a}$ & 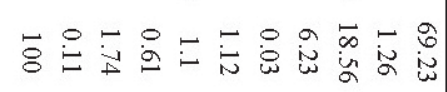 & in \\
\hline 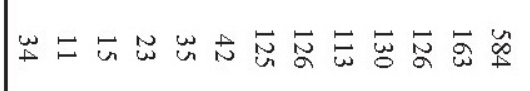 & b & 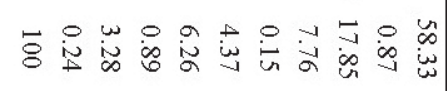 & $a$ \\
\hline : & 品 & 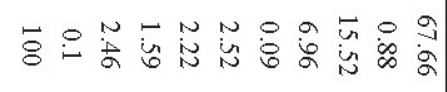 & \pm \\
\hline 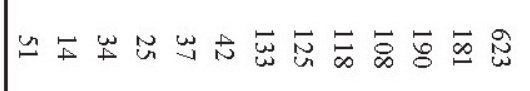 & $\stackrel{N}{\omega}$ & 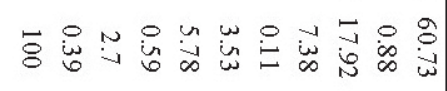 & 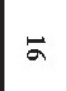 \\
\hline 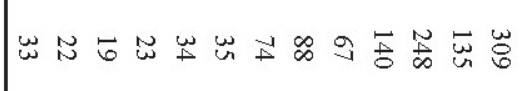 & N & 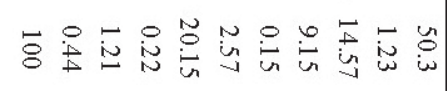 & $\exists$ \\
\hline 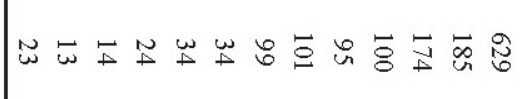 & 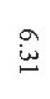 & 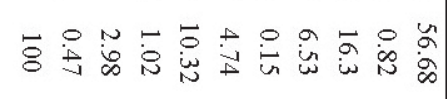 & $\vec{\infty}^{\infty}$ \\
\hline 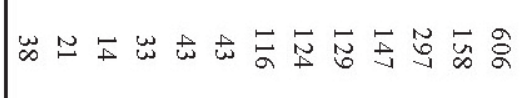 & $\vec{i}$ & 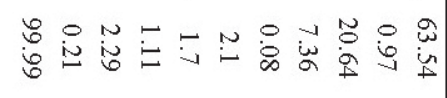 & $\mathscr{g}$ \\
\hline 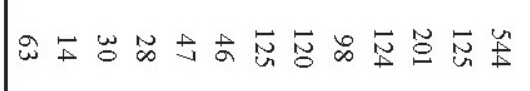 & ஜू & 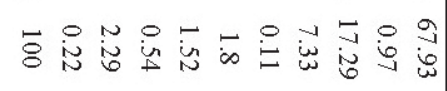 & $\stackrel{\iota}{\omega}$ \\
\hline w & & 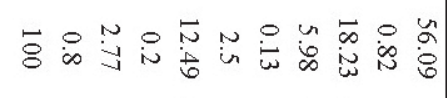 & $\underset{\sim}{u}$ \\
\hline 出品 & తै & 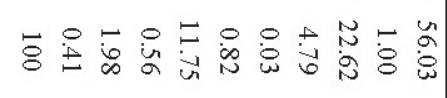 & \pm \\
\hline 光 & $\vec{\infty}$ & 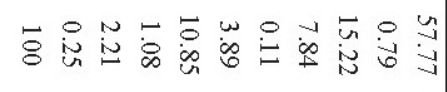 & $\Delta$ \\
\hline 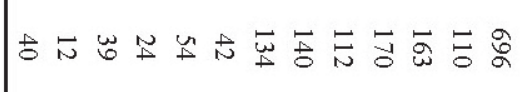 & $\stackrel{n}{i}$ & 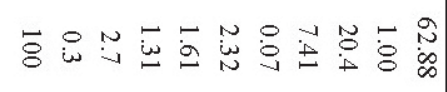 & $\exists$ \\
\hline 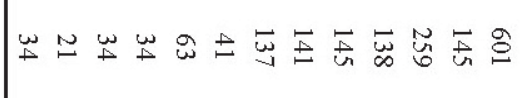 & $\rho$ & 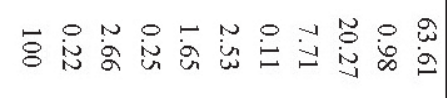 & $+\infty$ \\
\hline 하 & un & 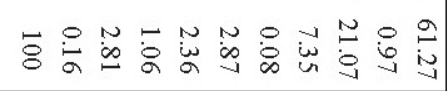 & $\stackrel{1}{\perp}$ \\
\hline 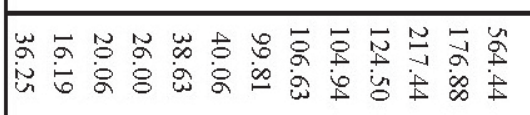 & & 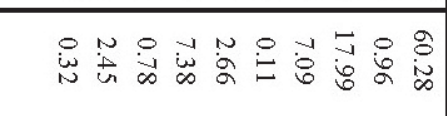 & 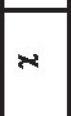 \\
\hline 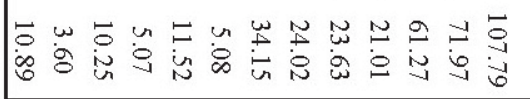 & & 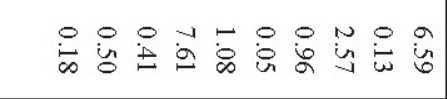 & a \\
\hline
\end{tabular}




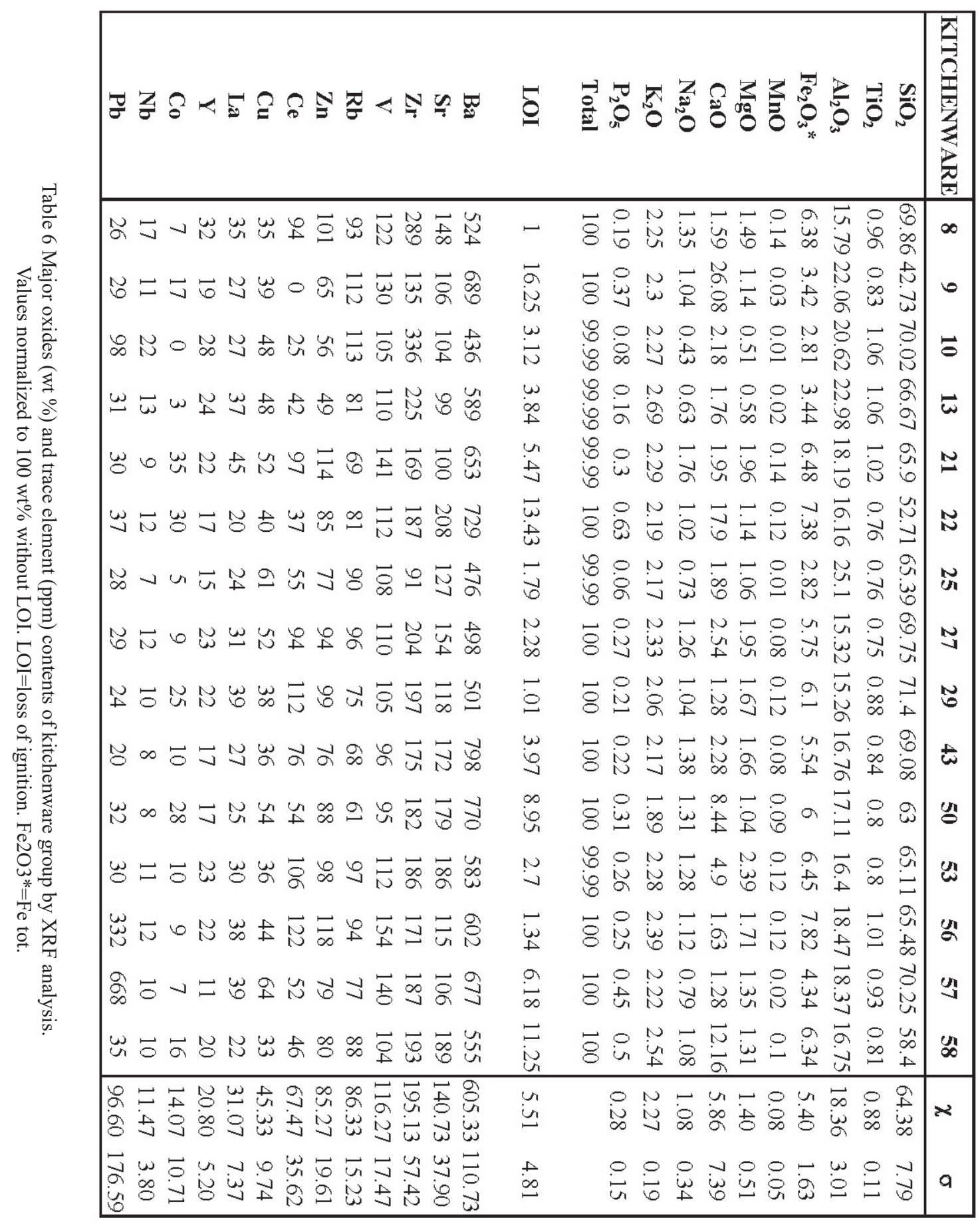




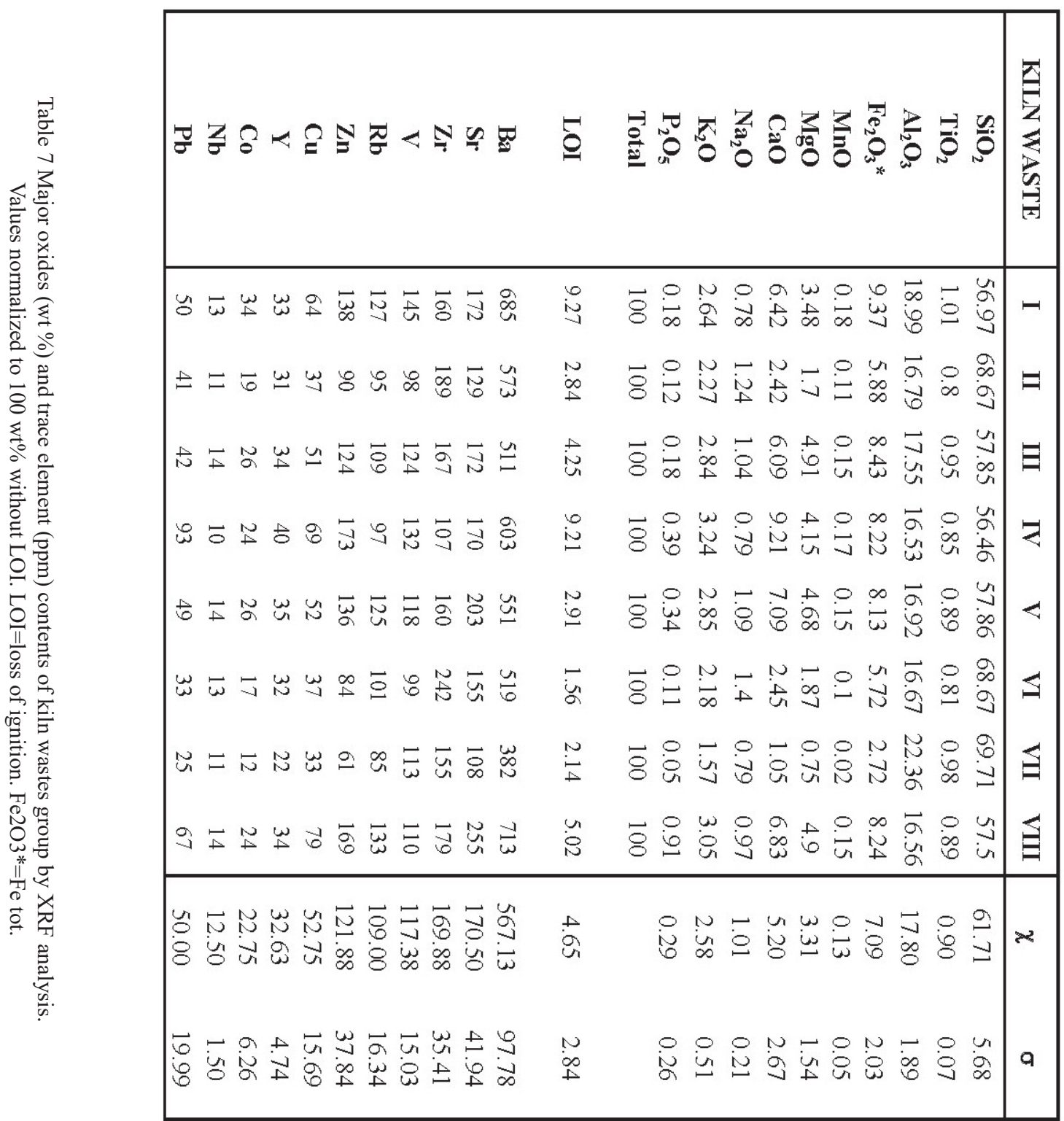

